\title{
Influence of Tobacco Additives on the Chemical Composition of Mainstream Smoke*
}

\author{
by \\ Jürgen Hahn' and Jutta Schaub ${ }^{2}$ \\ ${ }^{1}$ Chemisches und Veterinäruntersuchungsamt Sigmaringen (Official Chemical and Veterinary Surveillance Institute \\ Sigmaringen), Hedingerstrasse 2/1, 72488 Sigmaringen, Germany \\ ${ }^{2}$ Bundesministerium für Ernährung, Landwirtschaft und Verbraucherschutz (German Federal Ministry for Food, \\ Agriculture and Consumer Protection), Wilhelmstrasse 54, 10117 Berlin, Germany
}

\section{SUMMARY}

Additives used in tobacco product manufacturing are currently in the focus of public discussions with regard to potentially increased consumer health risks on account of certain additives. In addition, a few additives are suspected to enhance the addictiveness of tobacco products. In 2006, the German Federal Ministry for Food, Agriculture and Consumer Protection (Bundesministerium für Ernährung, Landwirtschaft und Verbraucherschutz, BMELV) commissioned a research project intended to provide support for the evaluation of additives and their influence on the composition and properties of cigarette mainstream smoke. In this paper the results of the study are reported. Different amounts of glycerol, cocoa powder and sucrose were added to the tobacco of two kinds of filter-ventilated King size test cigarettes with 'tar' levels of $6 \mathrm{mg}$ and $10 \mathrm{mg}$ per cigarette. The tobacco of the test cigarettes consisted of a commercially available blend made of Virginia, Burley and Oriental tobaccos. Machine smoking was performed according to the applicable ISO smoking regimen. Various smoke components, which are suspected to be harmful for health, were determined in mainstream smoke. Increasing levels of sucrose were correlated with an increase of the amount of formaldehyde but not of acetaldehyde in the mainstream smoke of the test cigarettes. In cigarettes with different levels of added glycerol no substantial change in smoke composition was observed. The addition of cocoa powder to tobacco resulted in a decrease of tobaccospecific $N$-nitrosamines in mainstream smoke. The results obtained in this study can be used as evidence for the toxicological evaluation aimed at approving or banning specific additives for tobacco product manufacturing.

[Beitr. Tabakforsch. Int. 24 (2010) 100-116]

\section{ZUSAMMENFASSUNG}

Die bei der Herstellung von Tabakerzeugnissen verwendeten Zusatzstoffe werden im Hinblick auf eine mögliche gesundheitsgefährdende Wirkung öffentlich diskutiert. Zusätzlich stehen einige Zusatzstoffe im Verdacht, die abhängig machende Wirkung von Tabakprodukten zu verstärken. Vom Bundesministerium für Ernährung, Landwirtschaft und Verbraucherschutz (BMELV) wurde 2006 ein Forschungsprojekt in Auftrag gegeben, das die Bewertung von Zusatzstoffen unterstützen und deren Einfluss auf die Zusammensetzung und die Eigenschaften von Tabakrauch untersuchen soll. Diese Arbeit fasst die Ergebnisse des Projektes zusammen.

Dem Tabak von zwei filterventilierten Kingsize-Testzigaretten mit unterschiedlichen Kondensatwerten (6 $\mathrm{mg}$ und $10 \mathrm{mg}$ pro Zigarette) wurden verschiedene Konzentrationen von Glycerin, Kakao (als Puder) und Saccharose zugesetzt. Der Tabak bestand aus einer marktüblichen Mischung aus Virginia-, Burley- und Orienttabak. Der Hauptstromrauch wurde mit Hilfe einer analytischen Rauchmaschine nach dem Abrauchregime der Internationalen Organisation für Normung (ISO) generiert. Verschiedene, als gesundheitsschädigend erachtete Rauchinhaltsstoffe, wurden im Hauptstromrauch der Testzigaretten bestimmt. Während ein steigender Saccharosegehalt zu einem Anstieg von Formaldehyd im Hauptstromrauch führte, konnte diese Korrelation für Acetaldehyd nicht beobachtet werden. Testzigaretten mit unterschiedlichem Glyceringehalt zeigten keine signifikanten Veränderungen in der Zusammensetzung des Tabakrauches im Vergleich zu der Referenzzigarette. Der Tabakzusatz von Kakaopulver resultierte in einer Abnahme von tabakspezifischen Nitrosaminen (TSNA). 
Die Daten dieses Forschungsprojektes können als Entscheidungshilfe für die toxikologische Bewertung und die Zulassung oder das Verbot von Zusatzstoffen bei der Herstellung von Tabakprodukten herangezogen werden. [Beitr. Tabakforsch. Int. 24 (2010) 100-116]

\section{RESUME}

Les additifs utilisés dans la fabrication des produits à base de tabac font actuellement l'objet de discussions publiques relatives à l'augmentation éventuelle des risques pour la santé des consommateurs liés à certains additifs. D'autre part, on soupçonne certains additifs d'augmenter la dépendance aux tabacs manufacturés. En 2006, le Ministère fédéral allemand de l'alimentation, de l'agriculture et de la protection des consommateurs (Bundesministerium für Ernährung, Landwirtschaft und Verbraucherschutz, BMELV) a commandé un projet de recherche visant à fournir un soutien pour l'évaluation des additifs et de leur influence sur la composition et les propriétés de la fumée principale de cigarettes. Ce document présente les résultats de cette étude. Différentes quantités de glycérine, de poudre de cacao et de saccharose ont été ajoutées au tabac de deux sortes de cigarettes tests avec filtres ventilées King size avec des niveaux de goudron de $6 \mathrm{mg}$ et $10 \mathrm{mg}$ par cigarette. Le tabac des cigarettes tests était constitué d'un mélange de tabacs Virginia, Burley et Oriental disponibles dans le commerce. La machine à fumer a été utilisée conformément au régime de fumage ISO en vigueur. Différents composants de la fumée, soupçonnés d'être nuisibles pour la santé, ont été déterminés dans la fumée principale. Des niveaux accrus de saccharose ont été mis en corrélation avec une augmentation de la quantité de formaldéhyde, mais pas d'acétaldéhyde, dans la fumée principale des cigarettes de test. Dans les cigarettes ayant des niveaux différents de glycérine ajouté aucun changement substantiel dans la composition de la fumée n'a été observé. L'ajout de poudre de cacao a entraîné une diminution des $N$-nitrosamines spécifiques au tabac dans la fumée principale. Les résultats obtenus lors cette étude peuvent servir de preuve pour l'évaluation toxicologique visant à améliorer ou à interdire certains additifs lors de la fabrication de produits à base de tabac. [Beitr. Tabakforsch. Int. 24 (2010) 100-116]

\section{INTRODUCTION}

\section{Regulatory background in Germany}

After the reform of the German Food Law in 1974, tobacco products were no longer considered food but treated as a separate product category under the new German Law on the Commercial Use of Foods, Tobacco Products, Cosmetics and Consumer Goods (Gesetz über den Verkehr mit Lebensmitteln, Tabakerzeugnissen, kosmetischen Mitteln und sonstigen Bedarfsgegenständen LMBG) (1). When a new food regulation came into force in the EU in 2002 (2), the relevant legislation in Germany had to be amended accordingly. Within the framework of the EU regulation, Germany issued, in 2005, the Law on the Reorganization of the Food and Feed Legislation (Gesetz zur Neuordnung des Lebensmittel- und Futtermittelrechts) the Code on Foods, Consumer Protection and Feed (Lebensmittel-, Bedarfsgegenstände- und Futtermittelgesetzbuch LFGB) (3). Regulations pertaining to tobacco products were included in the Provisional Tobacco Law (Vorläufiges Tabakgesetz) (4).

Inter alia, the Provisional Tobacco Law stipulates which tobacco products are allowed to be brought on the market and how they are to be monitored. Furthermore, the law empowers the Federal Ministry of Nutrition, Agriculture and Consumer Protection to set maximum levels for certain smoke constituents and requires manufacturers to inform the surveillance authorities about certain details, particularly the production and composition of tobacco products, the additives used in manufacturing, their function, the toxicity of these substances in burned or unburned form and their influence on the addictiveness of the product and on consumers health.

Since 1977, the use of additives has been regulated by the German Tobacco Ordinance (Tabakverordnung, TVO) (5). It specifies in detail which substances are permitted for manufacturing tobacco products, together with quality requirements, maximum inclusion levels and directions, in which specific tobacco product they may be used (Annex 1 of the Tobacco Ordinance). The Tobacco Ordinance works on the basis of the prohibitory principle: "Everything is prohibited unless it is explicitly allowed". For example, the Tobacco Ordinance defines precisely which plants or parts of plants, fruits, etc., may be used as additives for tobacco products, which solvents are allowed in and for the application of aromatic essences to the tobacco product or which materials may be used for cigarette filters, cigarette papers and adhesives, etc. Another list, a "negative list", defines certain substances, plants or their parts and specific substances that are explicitly prohibited for reasons of health protection. In addition to very precise designations, there are also non-specific terms such as "fruits", "fruit juice", "spirits" and "cocoa products". Moreover, "flavorings" that comply with the requirements of the German Flavoring Ordinance (Aromenverordnung) (6) may be used as additives in tobacco products without restrictions. These non-specific terms make it impossible to pinpoint the exact number of additives approved in Germany.

The German Tobacco Products Ordinance (TabakproduktVerordnung) (7) is based on the EU Tobacco Products Directive 2001/37/EC (8) and came into force in 2002. Among other things, the German Tobacco Products Ordinance - like comparable regulations in other EU member states - places manufacturers and importers of tobacco products under the obligation of making reports on the additives used. Every year, manufacturers and importers have to inform the responsible surveillance authorities of all additives used in the individual tobacco products, compiled in a list organized according to brand name and type and including quantities in descending order by percentage of weight (based on tobacco weight in finished product). Moreover, explanations have to be provided of the reasons for using the additives, together with available toxicological data on the additives, particularly in terms of health and addictive effects. For keeping consumers informed, the contents of the list are published in Germany on the internet 
in appropriate form by the Federal Office of Consumer Protection and Food Safety (Bundesamt für Verbraucherschutz und Lebensmittelsicherheit, BVL).

\section{Design and objectives of the study}

Cigarette tobacco may contain a large number of additives. The additives may be individual substances, such as humectants (glycerol, 1,2-propylene glycol), various sugars, aromatic substances like menthol and vanillin, or complex mixtures of aromatic compounds, seasonings, honey, cocoa, licorice, etc. According to Annex 1 of the Tobacco Ordinance and the publications released by the international tobacco industry, it is estimated that up to 500 additives may be used today in the production of cigarettes, as published by Doull et al. for cigarettes made for the U.S. market (9).

The additives for tobacco products are currently in the focus of public discussions with regard to possible health risk and addiction enhancing effects. More than 5000 substances are generated when tobacco burns (10) and according to the International Agency for Research on Cancer (IARC) more than 70 substances in tobacco smoke are classified as carcinogenic or very probably carcinogenic (11). In addition, it cannot completely be ruled out that the burning and pyrolysis processes during smoking generate harmful substances also from additives, thus compounding the risk for the consumer. Due consideration must, therefore, be given to the special aspects of the burning, pyrolysis and pyrosynthesis processes when assessing approved additives.

Two kinds of filter ventilated test cigarettes in King size format with mainstream smoke 'tar' contents of $10 \mathrm{mg}$ and $6 \mathrm{mg}$ (according to ISO 3308 (12)) were used in our study. The cigarettes were made from a commercially available, additive-free blend consisting of Virginia, Burley and Oriental tobaccos. The effects of different levels of the tobacco additives, glycerol, cocoa powder and sucrose, on the yields of several compounds in the mainstream smoke were studied and compared to additive-free reference cigarettes.

The literature data regarding the transfer and pyrolysis of the three additives, glycerol, cocoa powder and sucrose, show that it is not exactly clear which direct influence their addition to tobacco may have on the composition of mainstream smoke (13-24). Furthermore there is only limited comparability of the pyrolysis data because the studies in the literature are based on different experimental conditions which have a major effect on the pyrolysis products and their quantities. Over the last 50 years, numerous studies have been published on the influence of additives on cigarette smoke. A comprehensive review of the effects of tobacco additives on cigarette mainstream smoke was published by PASCHKE, HELLER and SCHERER in 2002 (25). Most publications are studies done by the tobacco industry and not by scientists unconnected to the cigarette industry. For the most part, these refer to studies of additive mixtures actually used in the production of cigarettes. However, the toxicological assessment of an additive has to look at the influence of the individual substance. In other words, the question whether an additive has an effect on the quantity of toxic substances in smoke can only be answered by comparing the smoke of cigarettes with and without the specific additive.

Originally, our intention was to examine the influence of certain additives only on the contents of tobacco-specific nitrosamines (TSNAs) and benzo $[a]$ pyrene $(\mathrm{B} a \mathrm{P})$ in cigarette mainstream smoke. These substances are primarily found in the particulate phase of tobacco smoke, whose composition and toxicity have been discussed in the literature in great detail (11). However, the number of compounds investigated was expanded by the addition of four gas phase components (formaldehyde, acetaldehyde, 1,3-butadiene and isoprene) as the toxicity and biological activity of tobacco smoke is brought about by substances in the gas-phase as well as the particulate phase $(26,27) .1,3-$ Butadiene and isoprene represent the volatile hydrocarbons in the gas phase. Formaldehyde and acetaldehyde are other toxic components of the gas phase, which were examined in our study because the correlation of their levels in tobacco smoke with the sugar content in tobacco has been discussed in the literature (28).

In summary, the influence of the additives under investigation on the yields of the following components in the mainstream smoke of experimental cigarettes was examined in our study:

- Carbon monoxide (CO)

- Nicotine

- Nicotine-free dry particulate matter (NFDPM), also referred to as 'tar'

- Tobacco-specific nitrosamines (TSNAs)

- Formaldehyde

- Acetaldehyde

- 1,3-Butadiene

- Isoprene

- Benzo[a]pyrene (BaP).

\section{DESCRIPTION OF THE ADDITIVES EVALUATED IN THE STUDY}

Glycerol

Glycerol is used in tobacco product manufacturing as a humectant. Together with other humectants, such as 1,2propanediol, the total amount in German cigarettes must not exceed the statutory maximum level of $5 \%$ of dry tobacco weight. This study was carried out with glycerol. Humectants are used in nearly all tobacco products and glycerol is one of the most frequently used.

A number of questions concerning the fate of glycerol in the tobacco column of a cigarette during smoking are still open. The relevant literature indicates that part of the glycerol added to the tobacco passes unchanged into the mainstream smoke the same way as many other volatile tobacco additives (13). However, the transfer rate depends to a great extent on the design of the cigarette. The share of glycerol found in mainstream smoke increases in proportion to the quantity of glycerol in the tobacco, ranging from $5 \%$ to $14 \%$ of the glycerol used. Studies with radiolabeled glycerol indicated that a portion could be detected also in the tobacco butt and the filter tip (14-16).

Although some of the glycerol in the tobacco is directly 
volatilized and can be detected in the smoke and filter, part of it is burned and pyrolyzed during smoking and suspected to be a major contributor to acrolein and aldehydes in tobacco smoke (29).

It was shown by pyrolizing neat glycerol as a liquid and as a vapor respectively, that the yields of the individual substances formed differ according to the chosen experimental conditions. While an earlier paper found in particular polycyclic hydrocarbons and phenols, together with various aldehydes and carboxylic acids (17), later data mainly revealed aldehydes and low-molecular hydrocarbon compounds as pyrolysis products of glycerol vapor (18). More recent publications of the tobacco industry examining experimental cigarettes containing glycerol report that, while a relatively large amount of the added glycerol is not pyrolyzed or burned (up to 95\%), nevertheless small quantities of acrolein and glycolaldehyde are generated (19). In 2010, YIP et al. reported that $0.25-0.30 \%$ of the added glycerol was converted to acrolein and acetone, detected in cigarette mainstream smoke (20).

\section{Cocoa powder}

Cocoa and cocoa products belong to the tobacco additives used as flavorings in so-called American Blend cigarettes. As a rule, they do not exceed $1.5 \%$ of the weight of tobacco in cigarettes sold in Germany. One natural component of cocoa is the pharmacologically active substance theobromine (with a share between 7 and 39\% (30)). As an additive in tobacco products for smoking, cocoa with its component, theobromine, is alleged to enlarge the pulmonary alveoli. It is speculated that this permits deeper inhalation of the smoke and could augment nicotine absorption in the lungs $(29,31,32)$. On the other hand, a report of the Dutch Ministry of Health comes to the conclusion that the exposure of the smoker to the basically psychoactive components, theobromine and caffeine, resulting from the addition of cocoa to cigarettes, is negligible as the uptake is too low to show any effect on the pulmonary system (30). Pyrolysis studies show that cocoa powder and cocoa shell extract generate mainly furfural and phenol by pyrolysis, together with cresol and styrene (21).

\section{Sucrose}

Various sugars are frequently added to tobacco by the tobacco industry in considerable quantities. The maximum quantity of sugar added to cigarettes during the production process amounts to approximately $5 \%$ of the tobacco weight. According to the tobacco industry, sugar is used to improve the taste of tobacco smoke. However, sugar and sugar compounds are also among the natural components of tobacco. The literature indicates that the total sugar content (mono- and disaccharides) of a Virginia cigarette, i.e. a cigarette without additives, may account for up to $20 \%$ of total tobacco weight due to the natural sugar in the tobacco (33). The total sugar content of so-called American Blend cigarettes is about $12 \%$, with the natural sugar content in tobacco accounting for about 8\% (28).

Sucrose is not volatile. Experimental data indicate that sucrose does not pass unchanged into mainstream smoke
(22). In experimental cigarettes, radioactively labeled sucrose is converted almost completely into various aldehydes, furans and ketones (23). A review article (24) states that polycyclic hydrocarbons predominate as the pyrolysis products of sucrose at higher temperatures (above $800^{\circ} \mathrm{C}$ ), compared to furanes and low-molecular carbonyl compounds at lower temperatures $\left(300-600^{\circ} \mathrm{C}\right)$.

\section{MATERIALS AND METHODS}

For our study, the 20 different test cigarettes were produced in the pilot plant of British American Tobacco (BAT) Germany. The production steps in making the cigarettes were comparable to the methods and techniques used in manufacturing factory cigarettes. An additive-free commercial tobacco blend consisting of 50\% Virginia tobacco (flue-cured), 20\% Burley tobacco (air-cured), 20\% tobacco stems and $10 \%$ Oriental tobacco (sun-cured) was used for the test cigarettes. Two kinds of filter-ventilated cigarettes in King size format with mainstream smoke condensate levels of $10 \mathrm{mg}$ and $6 \mathrm{mg}$ (according to ISO) were produced for this study. Cigarettes without any additives on tobacco were used as reference.

The three additives were added to the tobacco blend in the following target concentrations: Glycerol at 1.5\%, 3.0\% and $5.5 \%$; cocoa powder (fat content of $10-12 \%$ ) at $0.4 \%$, $1.1 \%$ and $2.2 \%$; sucrose (purity $>99 \%$ ) at $1.5 \%, 2.1 \%$ and $4.8 \%$. To obtain the target condensate levels for the two kinds of cigarettes they were designed differently. For the cigarettes with a condensate level of $10 \mathrm{mg}$ a cellulose acetate filter of $22 \mathrm{~mm}$ length with $27 \%$ ventilation was used, for the cigarettes with $6 \mathrm{mg}$ condensate the length of the filter plug was $27 \mathrm{~mm}$ and filter ventilation $47 \%$.

Efforts were made to keep the firmness of the cigarettes constant for both condensate levels independent from the kind and amount of additive used. Therefore, the amount of tobacco burned per puff during machine smoking can be considered comparable for the cigarettes of both condensate levels.

The specified condensate levels of $6 \mathrm{mg} / \mathrm{cig}$ and $10 \mathrm{mg} / \mathrm{cig}$ were primarily achieved by means of filter ventilation and filter plug length and efficiency. However, small changes in the degree of filter ventilation had to be made to achieve the precise condensate levels depending on the kind and amount of the added additives.

For the $10 \mathrm{mg}$ condensate cigarettes, the filter ventilation of $27 \%$ had to be reduced by $3 \%$ for samples with sucrose added at $2.1 \%$ and $4.8 \%$, and increased by $2 \%$ for the samples with a glycerol content of $5.5 \%$. For the $6 \mathrm{mg}$ condensate cigarettes, the degree of filter ventilation of $47 \%$ had to be increased by $2 \%$ for samples with glycerol added at $5.5 \%$.

The lowest additive concentration in each case corresponds to the typical concentration in commercially available products. The higher additive concentrations were evaluated mainly from an experimental point of view for examining possible dose-effect relationships regarding the composition of mainstream smoke.

The samples with $10 \mathrm{mg}$ condensate had an average tobacco rod weight of $674 \mathrm{mg}$, compared to $611 \mathrm{mg}$ for $6 \mathrm{mg}$ condensate - a consequence of using filters with two 
different lengths.

After conditioning according to ISO 3402 (34) the cigarettes were smoked according to ISO 3308 (12) on a rotary RM20H (Borgwaldt-KC) smoking machine. The nicotine content of mainstream smoke and nicotine-free condensate were determined according to ISO 10315 (35) and ISO 4387 (smoking of the cigarettes on an automatic smoking machine with simultaneous collection of total particulate matter in a glass fiber trap; gravimetric determination of the mass of total particulate matter; extraction of the total particulate matter with isopropanol from the trap for the determination of water and nicotine by gas chromatography (GC) (36). The water content was determined according to ISO 10362-2 (37) and mainstream smoke carbon monoxide according to ISO 8485 (38). The carbon monoxide yield of the total gas phase of the smoke was determined by non-dispersive infrared analysis.

For the determination of formaldehyde and acetaldehyde cigarette mainstream smoke was generated from ten cigarettes. The whole mainstream tobacco smoke was scrubbed of volatile carbonyls by passing each puff through an impinger into a trap containing an acidified solution of 2,4-dinitrophenylhydrazine in acetonitrile. The determination itself was done by high-performance liquid chromatography with UV Detector (HPLC-UV) using diode array detection (DAD) (39).

The tobacco specific $N$-nitrosamines, $N$-nitrosonornicotine (NNN), 4-( $N$-nitrosomethylamino)-1-(3-pyridyl)-1-butanone (NNK), $N$-Nitrosoanatabine (NAT) and $N$-nitrosoanabasine (NAB), in mainstream smoke were determined by high-performance liquid chromatography tandem mass spectrometry (HPLC-MS/MS) according to the relevant Official Methods of Health Canada (40). The mainstream smoke of 20 cigarettes was collected on a Cambridge filter and extracted with ammonium acetate solution.

The benzo $[a]$ pyrene yield was determined in the mainstream smoke of 20 cigarettes by extracting total particulate matter, collected on the glass-fiber filter pad ("Cambridge filter"), with cyclohexane. The analytical determination by gas chromatography-mass spectrometry (GC/MS) using single ion monitoring detection mode was done according to the relevant Health Canada Method (41).

For the determination of 1,3-butadiene and isoprene the mainstream smoke of 20 cigarettes was collected in cooled methanol traps. The determination was done by GC/MS according to relevant Methods of Health Canada (42).

Considering the high variance resulting from analytical and product-related fluctuations each mainstream smoke component was determined in 10 replicates.

The CORESTA monitor cigarette CM6 and internal monitor cigarettes - all with known, well documented 'tar', nicotine and carbon monoxide mainstream smoke levels were smoked to assure the quality of the machine smoking procedure.

The glycerol in the tobacco of the test cigarettes was determined by gas chromatography (43). The cocoa content was determined indirectly by high-performance liquid chromatography (HPLC), measuring its theobromine content (44). Sucrose was determined by HPLC according to DIN 10371 (45), measuring glucose, fructose and sucrose in tobacco and tobacco products by HPLC.
Table 1. Targeted and measured levels of glycerol in experimental cigarettes (based on dry tobacco weight)

\begin{tabular}{l|c|c|c|c}
\hline \multirow{2}{*}{ Glycerol content } & \multicolumn{2}{|c|}{$6 \mathrm{mg}$ 'tar' } & \multicolumn{2}{c}{$10 \mathrm{mg}$ 'tar' } \\
\cline { 2 - 5 } & target & actual & target & actual \\
\hline \multirow{2}{*}{ Reference cigarettes } & - & 0.2 & - & 0.2 \\
& 1.5 & 1.2 & 1.5 & 1.2 \\
Test cigarettes & 3.0 & 2.9 & 3.0 & 3.0 \\
& 5.5 & 5.2 & 5.5 & 5.2 \\
\hline
\end{tabular}

Table 2. Targeted and measured levels of cocoa in experimental cigarettes (based on dry tobacco weight)

\begin{tabular}{l|c|c|c|c}
\hline \multirow{2}{*}{ Cocoa content } & \multicolumn{2}{|c|}{$6 \mathrm{mg}$ 'tar' } & \multicolumn{2}{c}{$10 \mathrm{mg}$ 'tar' } \\
\cline { 2 - 5 } & target & actual & target & actual \\
\hline \multirow{2}{*}{ Reference cigarettes } & - & 0 & - & 0 \\
& 0.4 & 0.36 & 0.4 & 0.39 \\
Test cigarettes & 1.1 & 1.15 & 1.1 & 1.13 \\
& 2.2 & 1.74 & 2.2 & 2.18 \\
\hline
\end{tabular}

Table 3. Targeted and measured levels of sucrose in experimental cigarettes (based on dry tobacco weight)

\begin{tabular}{l|cc|c|c}
\hline \multirow{2}{*}{ Sucrose content } & \multicolumn{2}{|c|}{$6 \mathrm{mg}$ 'tar' } & \multicolumn{2}{c}{$10 \mathrm{mg}$ 'tar' } \\
\cline { 2 - 5 } & target & actual & target & actual \\
\hline Reference cigarettes & - & 0.68 & - & 0.64 \\
& 1.5 & 1.5 & 1.5 & 1.4 \\
Test cigarettes & 2.1 & 2.2 & 2.1 & 2.3 \\
& 4.8 & 4.3 & 4.8 & 5.1 \\
\hline
\end{tabular}

\section{RESULTS}

\section{Characterization of the test cigarettes}

The measured concentrations of the additives, glycerol, cocoa powder, and sucrose in the tobacco blend confirmed that the manufacturing targets were met for all three additives to the extent technically feasible.

It should be noted that tobacco as a natural material already contains glycerol and sucrose. The glycerol and sucrose contents of the tobacco in the reference cigarettes (without additives) were determined while the test samples were being produced. The analysis showed an average level of $0.2 \%$ for glycerol and $0.7 \%$ for sucrose.

The glycerol concentration was chosen to be both within the range of practical use and above the statutory maximum limit (5\% in the tobacco dry matter), with target concentrations of $1.5 \%, 3.0 \%$, and $5.5 \%$ (Table 1 ).

The targets for the total cocoa powder content in the tobacco blend were achieved with good accuracy (Table 2). The sucrose content in the two reference cigarettes amounted to $0.64 \%$ and $0.68 \%$, respectively. The sucrose content stated in the table corresponds to the sum of natural sucrose in the initial blend plus added sucrose (Table 3 ). During production, the initial tobacco weight per cigarette 
was to be kept constant within the condensate level. To check this, three cigarettes were weighed per additive for each condensate level together with the reference cigarette. The weight of paper and filter was then subtracted from the overall weight.

\section{Results for the mainstream smoke components under investigation}

- Carbon monoxide, nicotine and nicotine-free dry particulate matter

The results obtained by analyzing the test and reference cigarettes are shown in Figure 1 (carbon monoxide), Figure 2 (nicotine in smoke) and Figure 3 (nicotine-free dry particulate matter (NFDPM)).

There were no differences in the basic parameters carbon monoxide, nicotine and nicotine-free dry particulate matter with regard to the various additions of glycerol, cocoa powder and sucrose (Figures 1, 2, and 3). The data show that production of the reference and test cigarettes with the corresponding targets for nicotine-free dry particulate matter was successful when considering the analytical and production-related fluctuations and pursuant to the internationally recognized ISO smoking methods.

\section{- Tobacco-specific nitrosamines (TSNAs)}

Our results concerning the influence of the three tobacco additives on the yields of tobacco-specific nitrosamines (TSNAs) in mainstream smoke are shown in the Figures 4-7.

Tobacco-specific nitrosamines (TSNAs) are generated in harvested tobacco by the nitrozation of tobacco alkaloids during curing and fermentation. The final TSNA levels in tobacco depend on the kind of tobacco and on the conditions during cultivation, curing techniques, subsequent storage and processing of the tobacco leaf (46). In our study, the TSNA levels in the mainstream smoke of the test cigarettes with additives are generally reduced compared to the reference cigarettes. With glycerol as an additive a dosedependent trend is obvious for all four TSNAs.

\section{- Components of the gas / vapor phase}

The influence of the three additives on the mainstream smoke yields of formaldehyde and acetaldehyde seen in our study is shown in Figures 8 and 9.

The effect of the three tobacco additives in the cigarette blend on formaldehyde yields in mainstream smoke is shown in Figure 8. The addition of glycerol results in a slight decrease of formaldehyde. The formaldehyde levels in the mainstream smoke of the test cigarettes with cocoa powder as additive are within the range of the reference cigarettes for both condensate levels. As shown by BAKER (47) the sugar content of tobacco correlates directly with the formaldehyde yield in cigarette mainstream smoke. Also in our study, we found a clear increase of formaldehyde in mainstream smoke of the $10 \mathrm{mg}$ condensate cigarettes correlated with the amount of added sucrose to the blend. However, this effect was not equally pronounced in the mainstream smoke of the $6 \mathrm{mg}$ condensate cigarettes.
In the test cigarettes, the inclusion levels of glycerol $(1.2 \%$, $2.9 \%, 5.2 \%$ ) were substantially higher than those of cocoa powder $(0.36 \%, 1.15 \%, 1.74 \%)$ resulting in more severe reductions of cigarette tobacco weight. In addition, the variability of the analytical method for measuring formaldehyde is generally higher than with the other analytes.

Tobacco burning generates among other compounds various aldehydes that occur primarily in the gas phase of smoke. In our study, the additives under investigation had no essential influence on the levels of acetaldehyde in cigarette mainstream smoke (Figure 9).

Figure 10 shows the effects of the tobacco additives, glycerol, cocoa powder and sucrose, on the yield of 1,3butadiene found in mainstream smoke.

The $10 \mathrm{mg}$ test cigarettes showed an increase in 1,3-butadiene in mainstream smoke compared to the reference cigarette, while no increase was observed in the $6 \mathrm{mg}$ cigarette samples, regard being given to analytical variability. The addition of sucrose to the $10 \mathrm{mg}$ cigarette resulted in an obvious increase of 1,3-butadiene. It should be noted that the difference between the means of the $10 \mathrm{mg}$ and the $6 \mathrm{mg}$ test cigarettes is larger than the difference between the two additive-free reference cigarettes. This suggests that the measured levels of 1,3-butadiene are too low in the $10 \mathrm{mg}$ reference cigarettes. The relatively large increase in 1,3butadiene for the $3 \%$ addition of glycerol may be due to production-related differences.

The data regarding the influence of the tobacco additives tested on the amount of isoprene in mainstream smoke are shown in Figure 11.

No meaningful differences between the $6 \mathrm{mg}$ condensate test cigarettes and the corresponding reference cigarettes were seen in the yields of the two compounds isoprene and 1,3butadiene in the gas phase of mainstream smoke.

\section{- Benzo[a]pyrene}

The effect of the additives on mainstream smoke yields of benzo $[a]$ pyrene is shown in Figure 12. In comparison to the benzo $[a]$ pyrene levels in the mainstream smoke of the two reference cigarettes there is no substantial difference observed in the test cigarettes. The variations in the benzo[ $a]$ pyrene levels seen may result from factors related to the production of the cigarettes or variations in the analytical methods.

\section{DISCUSSION}

There have been intensive public discussions about the purpose and toxicological effects of additives in tobacco products $(29,31,32)$. Criticism was focused in particular on additives with a potential influence on the addictive effects of tobacco smoke or with chemical properties suggesting the formation of toxic compounds when burned and pyrolyzed, this way augmenting the overall toxicity of tobacco smoke.

In our study the effects of the tobacco additives, glycerol, cocoa powder and sucrose, on the level of various selected components in mainstream smoke were evaluated. Most relevant data published to date originated either directly or indirectly from the tobacco industry. This study was com- 


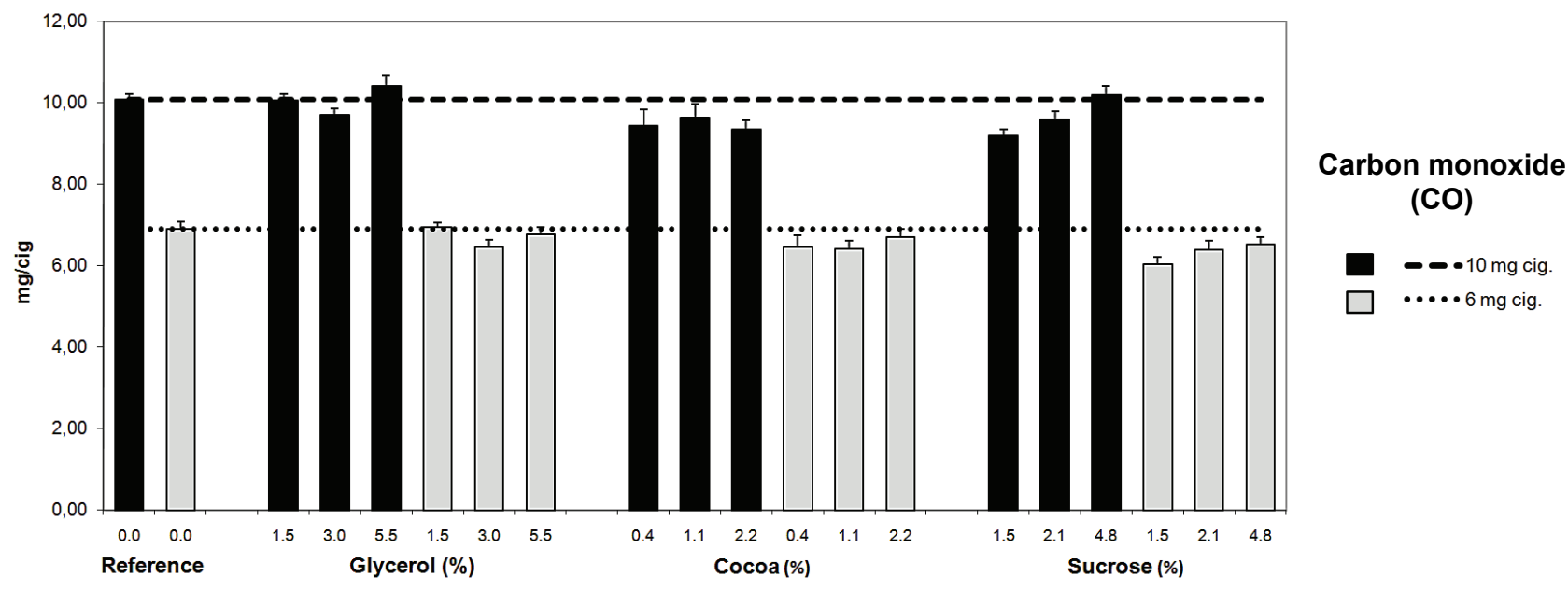

Figure 1. Carbon monoxide (CO) yields in mainstream smoke for different additive levels of glycerol, cocoa, and sucrose in two experimental cigarettes $(6 \mathrm{mg}, 10 \mathrm{mg}$ nicotine-free dry particulate matter according to ISO smoking regimen). Reference cigarettes without additives. Bars and error indicators represent mean and standard deviation of 10 measurements.

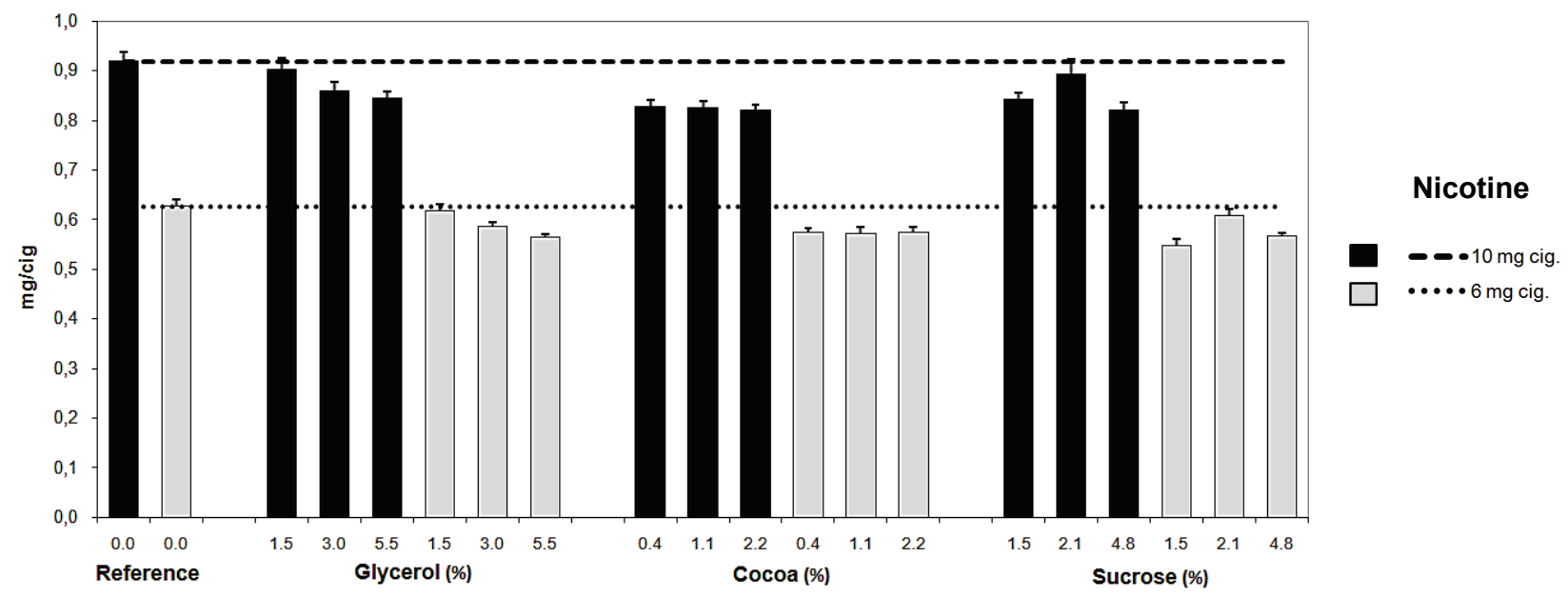

Figure 2. Nicotine yields in mainstream smoke for different additive levels of glycerol, cocoa, and sucrose in two experimental cigarettes $(6 \mathrm{mg}, 10 \mathrm{mg}$ nicotine-free dry particulate matter according to ISO smoking regimen). Reference cigarettes without additives. Bars and error indicators represent mean and standard deviation of 10 measurements.

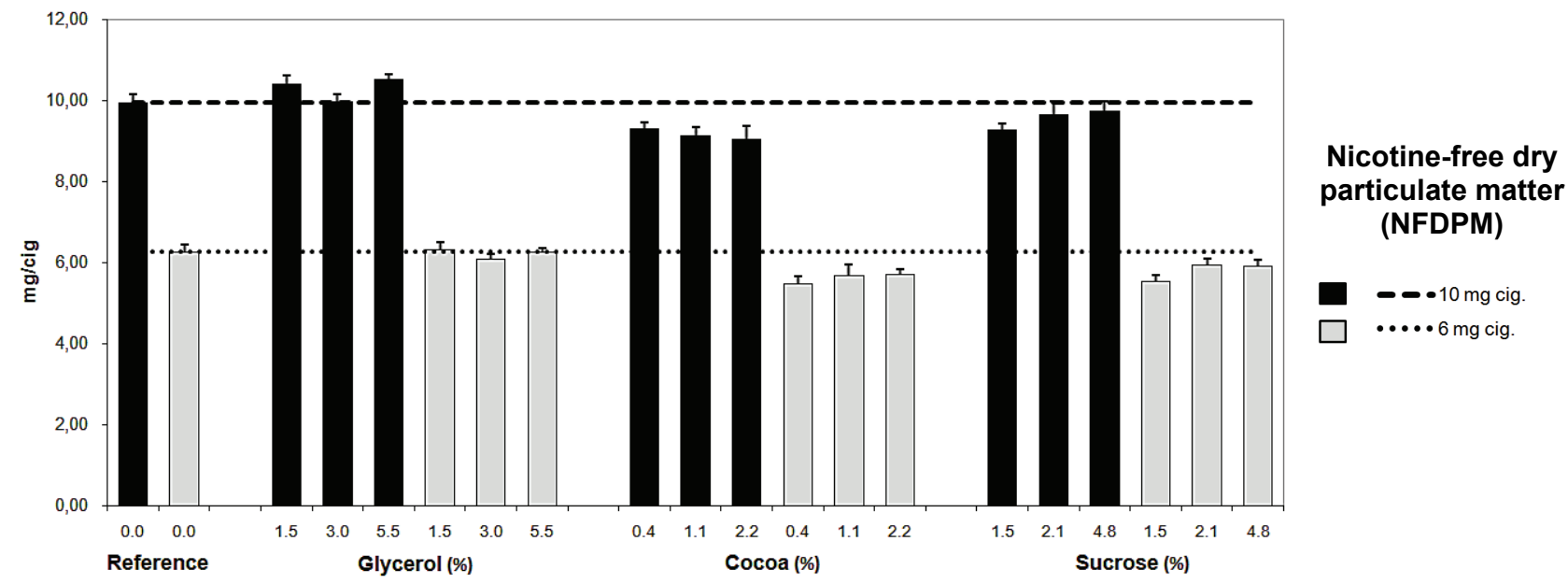

Figure 3. Nicotine-free dry particulate matter (NFDPM) yields in mainstream smoke for different additive levels of glycerol, cocoa, and sucrose in two experimental cigarettes $(6 \mathrm{mg}, 10 \mathrm{mg}$ nicotine-free dry particulate matter according to ISO smoking regimen). Reference cigarettes without additives. Bars and error indicators represent mean and standard deviation of 10 measurements. 


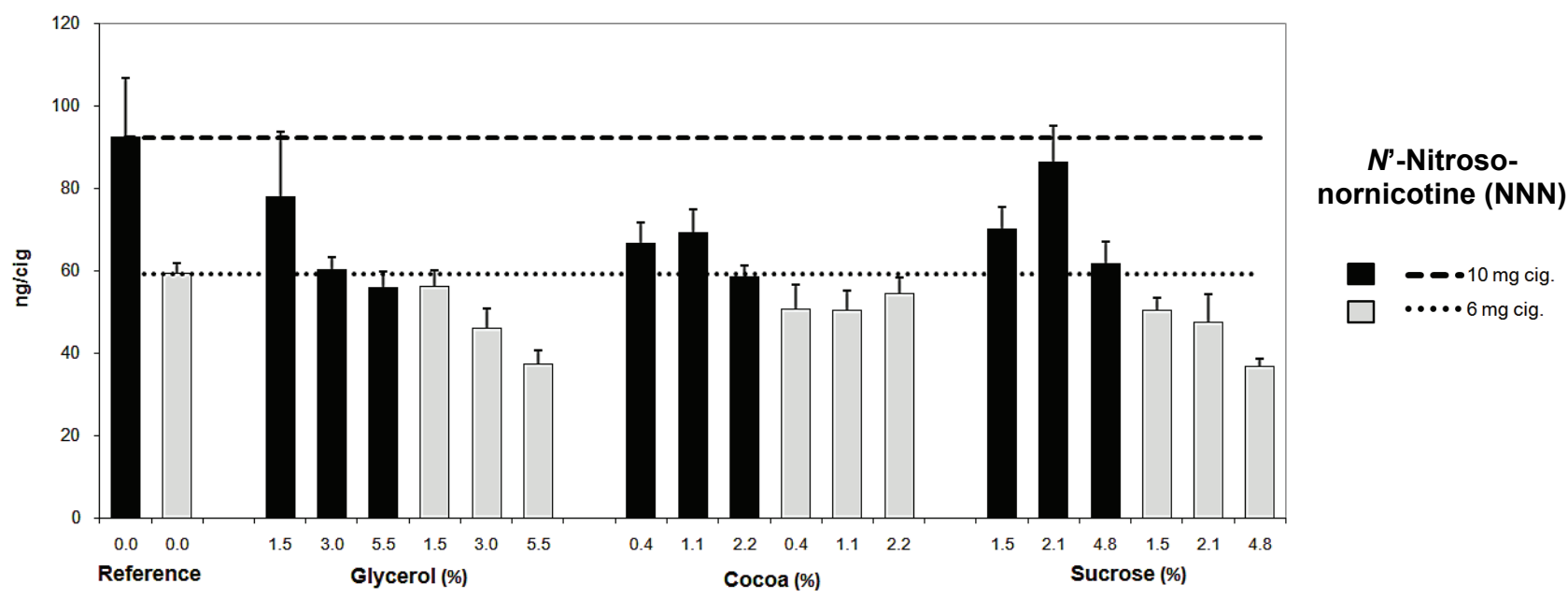

Figure 4. $N^{\prime}$-Nitrosonornicotine (NNN) yields in mainstream smoke for different additive levels of glycerol, cocoa, and sucrose in two experimental cigarettes $(6 \mathrm{mg}, 10 \mathrm{mg}$ nicotine-free dry particulate matter according to ISO smoking regimen). Reference cigarettes without additives. Bars and error indicators represent mean and standard deviation of 10 measurements.

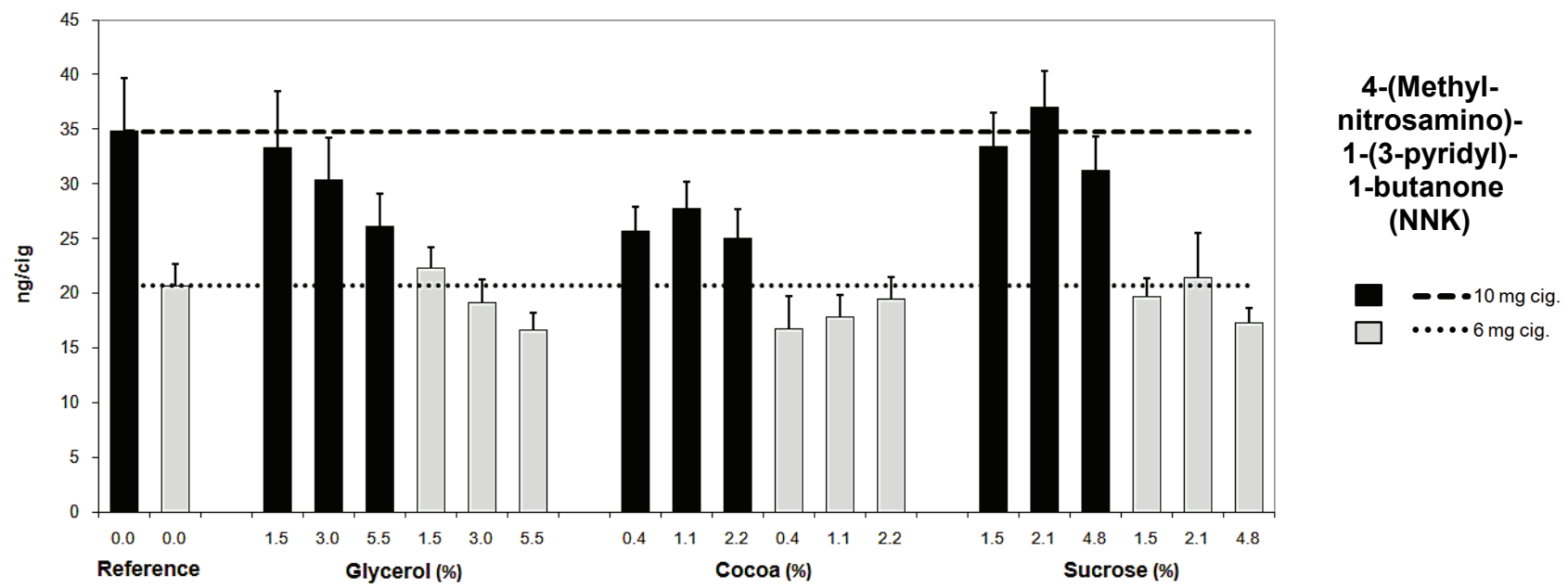

Figure 5. 4-(Methylnitrosamino)-1-(3-pyridyl)-1-butanone (NNK) yields in mainstream smoke for different additive levels of glycerol, cocoa, and sucrose in two experimental cigarettes $(6 \mathrm{mg}, 10 \mathrm{mg}$ nicotine-free dry particulate matter according to ISO smoking regimen). Reference cigarettes without additives. Bars and error indicators represent mean and standard deviation of 10 measurements.

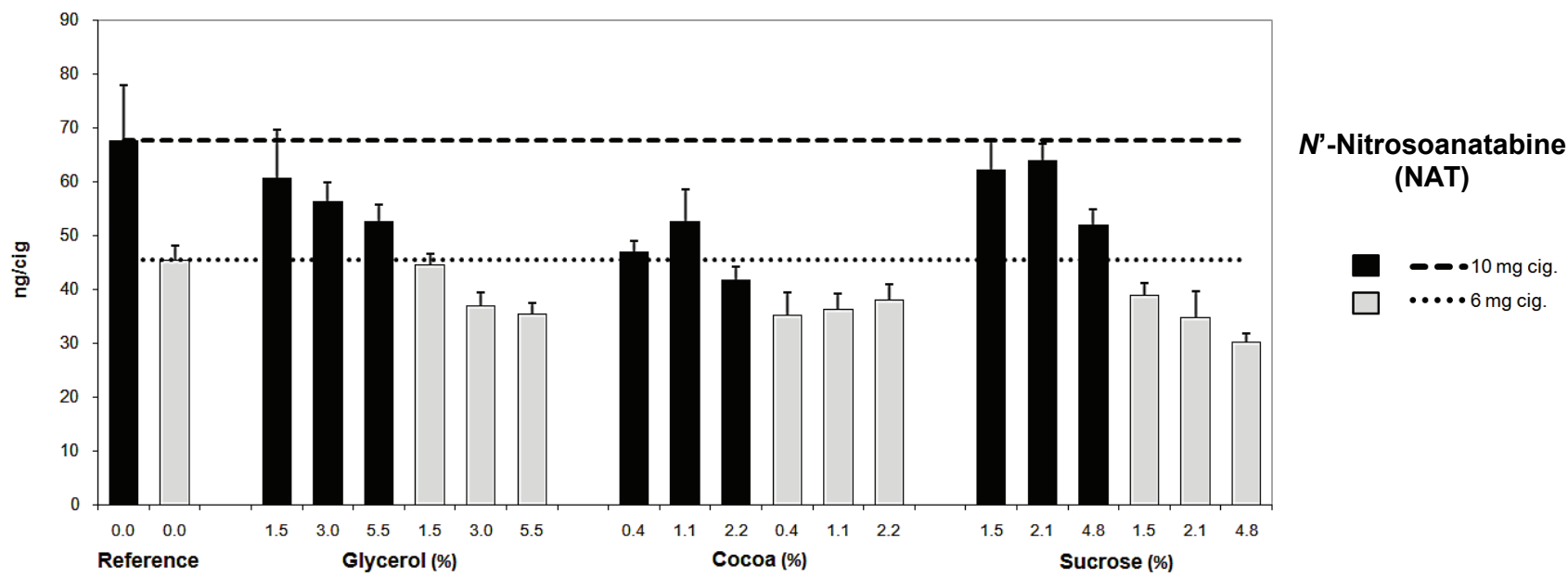

Figure 6. $N$ '-Nitrosoanatabine (NAT) yields in mainstream smoke for different additive levels of glycerol, cocoa, and sucrose in two experimental cigarettes $(6 \mathrm{mg}, 10 \mathrm{mg}$ nicotine-free dry particulate matter according to ISO smoking regimen). Reference cigarettes without additives. Bars and error indicators represent mean and standard deviation of 10 measurements. 


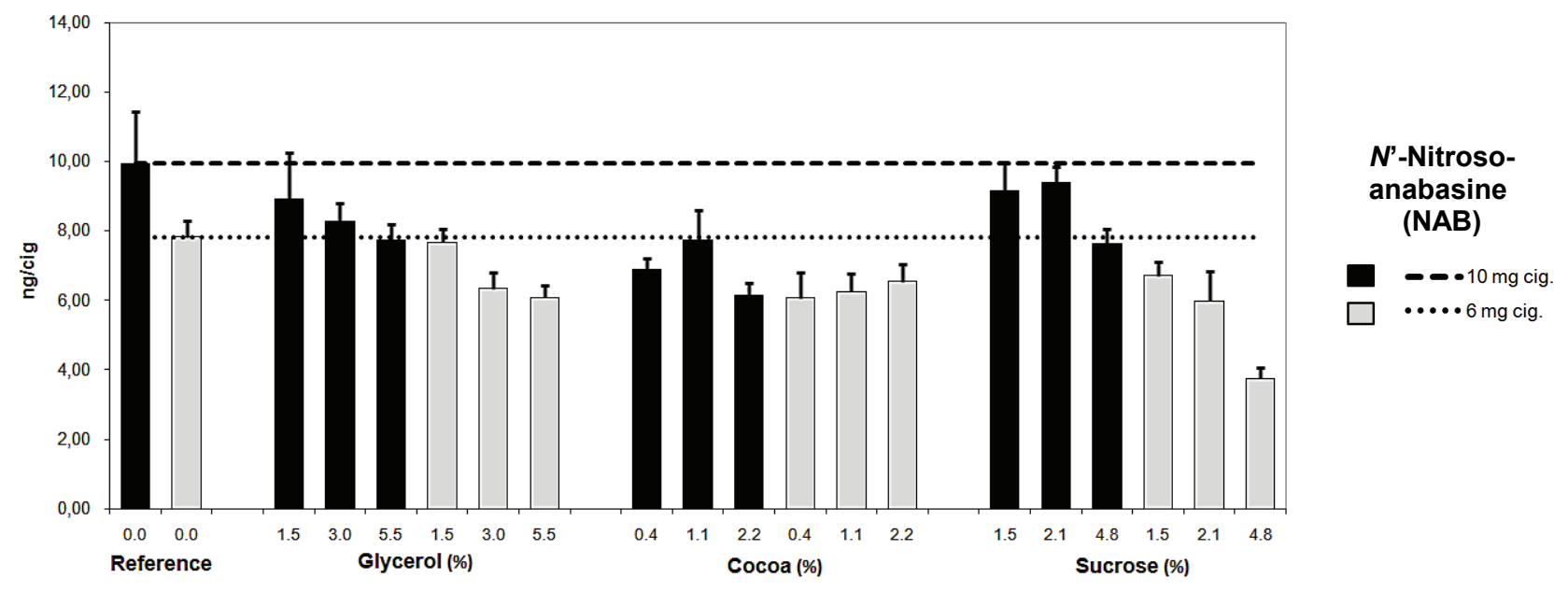

Figure 7. $N^{\prime}$-nitrosoanabasine (NAB) yields in mainstream smoke for different additive levels of glycerol, cocoa, and sucrose in two experimental cigarettes $(6 \mathrm{mg}, 10 \mathrm{mg}$ nicotine-free dry particulate matter according to ISO smoking regimen). Reference cigarettes without additives. Bars and error indicators represent mean and standard deviation of 10 measurements.

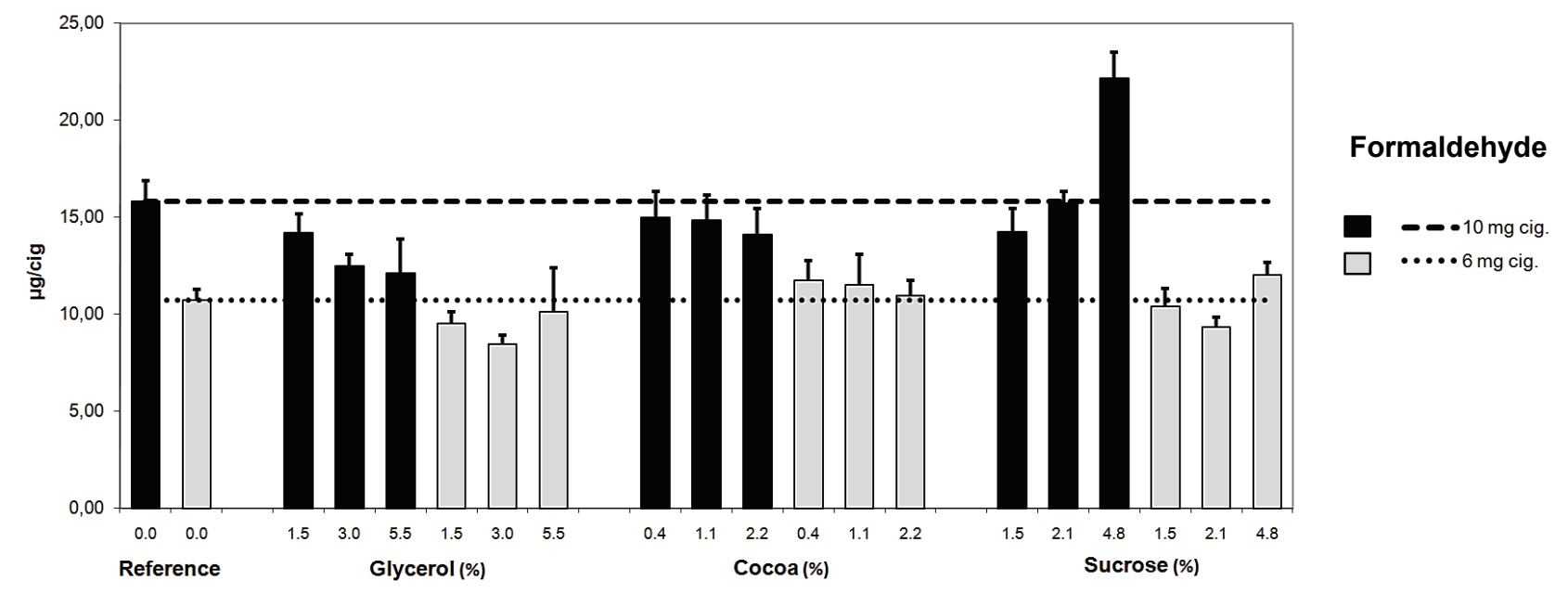

Figure 8. Formaldehyde yields in mainstream smoke for different additive levels of glycerol, cocoa, and sucrose in two experimental cigarettes (6 mg, $10 \mathrm{mg}$ nicotine-free dry particulate matter according to ISO smoking regimen). Reference cigarettes without additives. Bars and error indicators represent mean and standard deviation of 10 measurements.

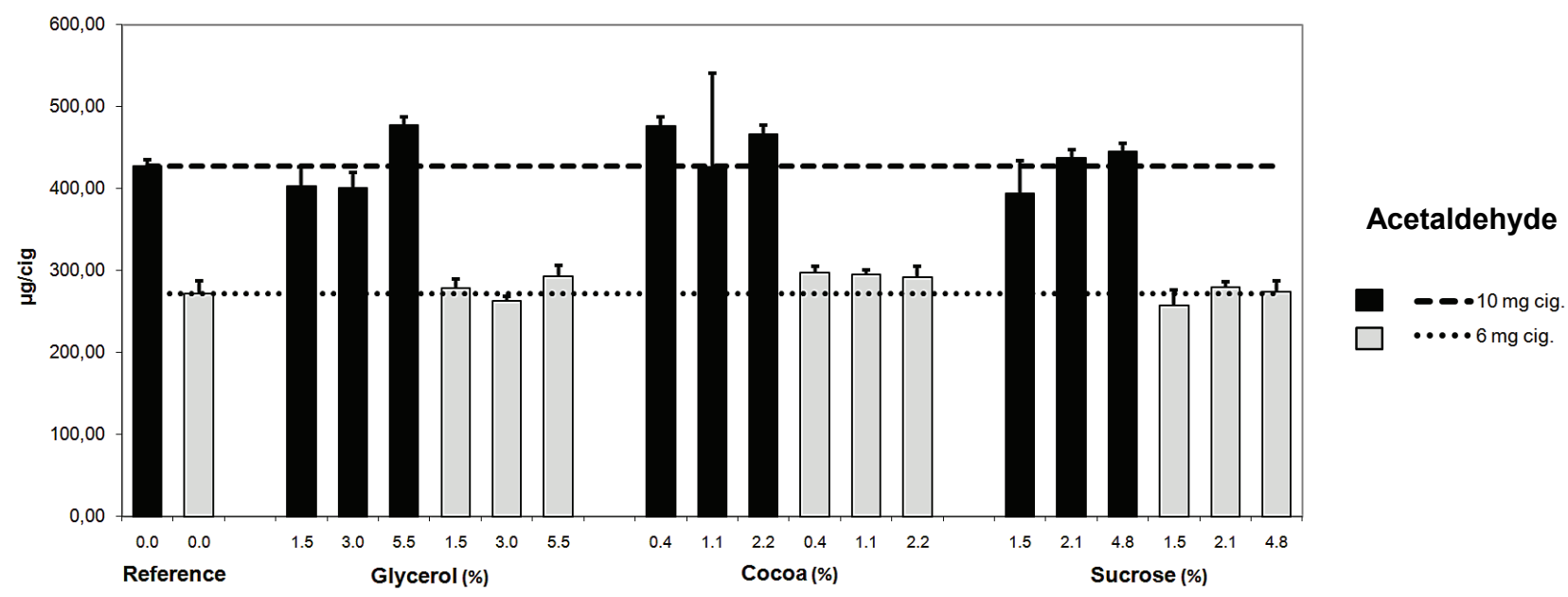

Figure 9. Acetaldehyde yields in mainstream smoke for different additive levels of glycerol, cocoa, and sucrose in two experimental cigarettes (6 mg, $10 \mathrm{mg}$ nicotine-free dry particulate matter according to ISO smoking regimen). Reference cigarettes without additives. Bars and error indicators represent mean and standard deviation of 10 measurements. 


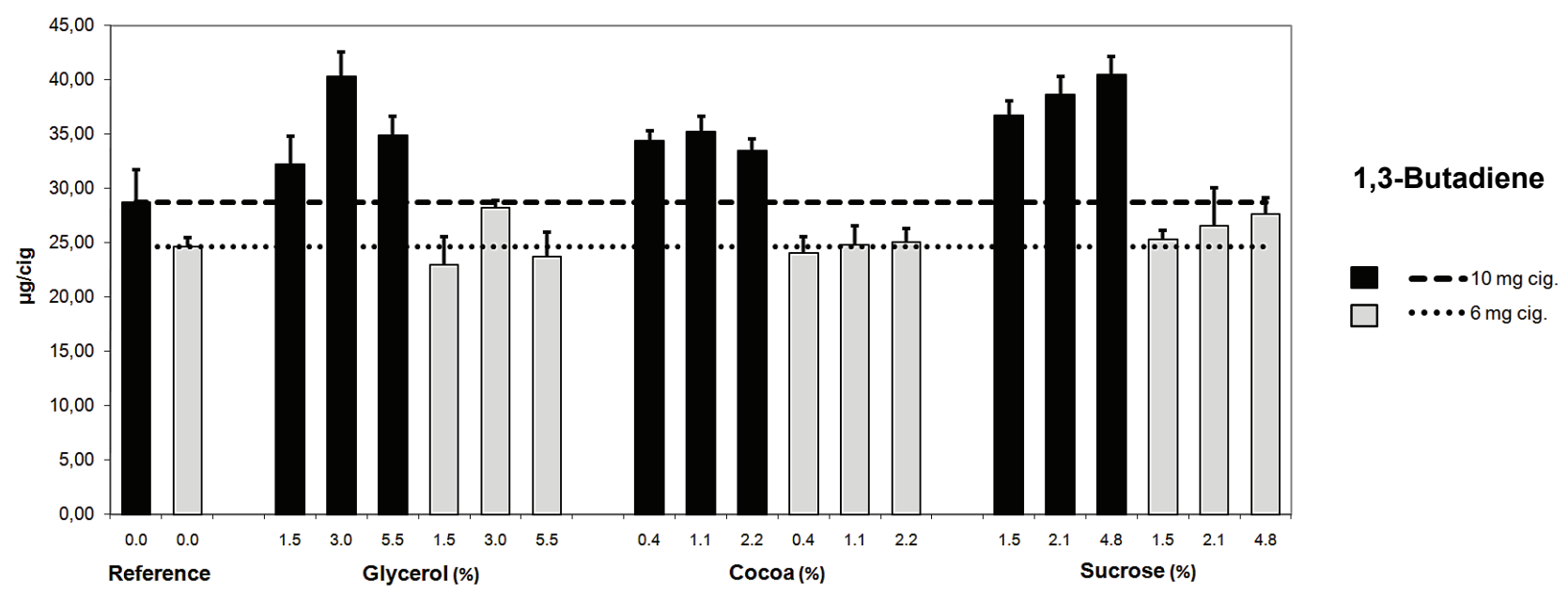

Figure 10. 1,3-Butadiene yields in mainstream smoke for different additive levels of glycerol, cocoa, and sucrose in two experimental cigarettes $(6 \mathrm{mg}, 10 \mathrm{mg}$ nicotine-free dry particulate matter according to ISO smoking regimen). Reference cigarettes without additives. Bars and error indicators represent mean and standard deviation of 10 measurements.

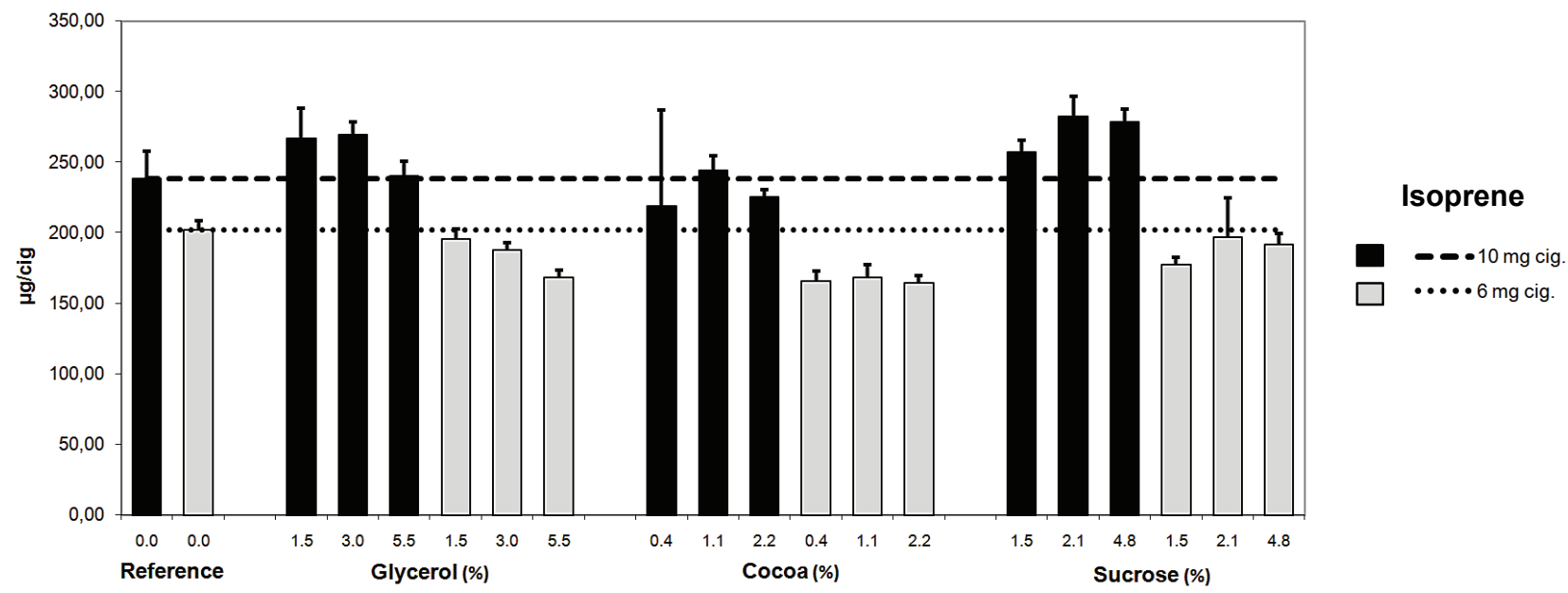

Figure 11. Isoprene yields in mainstream smoke for different additive levels of glycerol, cocoa, and sucrose in two experimental cigarettes $(6 \mathrm{mg}, 10 \mathrm{mg}$ nicotine-free dry particulate matter according to ISO smoking regimen). Reference cigarettes without additives. Bars and error indicators represent mean and standard deviation of 10 measurements.

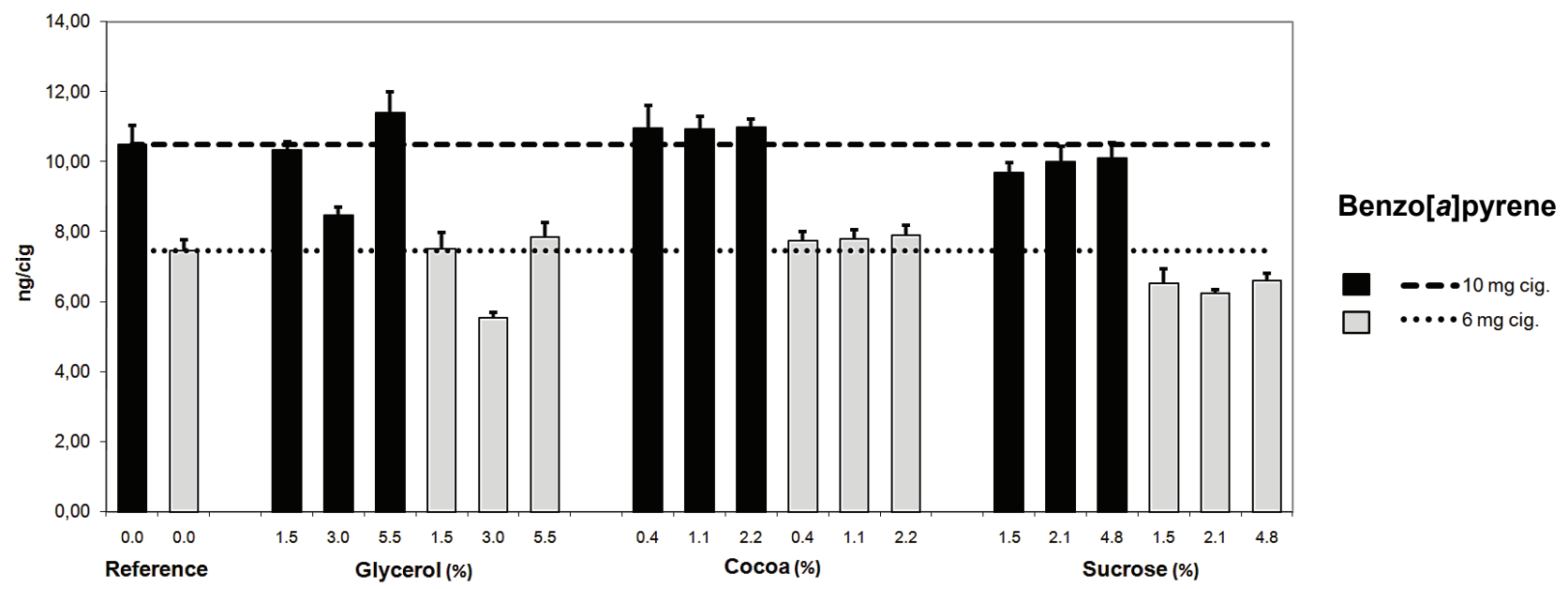

Figure 12. Benzo[a]pyrene yields in mainstream smoke for different additive levels of glycerol, cocoa, and sucrose in two experimental cigarettes (6 mg, $10 \mathrm{mg}$ nicotine-free dry particulate matter according to ISO smoking regimen). Reference cigarettes without additives. Bars and error indicators represent mean and standard deviation of 10 measurements. 
missioned by the BMELV, the German Federal Ministry for Food, Agriculture and Consumer Protection.

Our paper on the effects of tobacco additives on the yields of specific toxic components in cigarette mainstream smoke is one of the few publications released by an independent government-owned monitoring laboratory.

\section{Assessment of the additives under investigation, glycerol, cocoa powder, and sucrose}

The chemical analysis of the mainstream smoke of the test cigarettes with glycerol as tobacco additive revealed no essential changes compared to the mainstream smoke of the additive-free reference cigarettes. In particular, no unequivocal dose-effect relationships were observed between the amounts of additives added and the yields of the analytes in question in cigarette mainstream smoke. Glycerol was shown to have no influence on the levels of benzo $[a]$ prene, isoprene and acetaldehyde in smoke. A slight decrease was observed in the yields of tobaccospecific nitrosamines and nicotine. Even with the addition of $5 \%$ glycerol, the yields of formaldehyde were in the range of analytical variation. Inconsistent increases were observed for 1,3-butadiene with the $10 \mathrm{mg}$ 'tar' test cigarettes. As mentioned before, this may be due to production-related differences for the $3 \%$ glycerol test cigarette and an inadequately low level of 1,3-butadiene in the $10 \mathrm{mg}$ reference cigarette.

It has been reported that the levels of tobacco-specific nitrosamines and nicotine in smoke show a tendency to decrease with the addition of glycerol, particularly when the condensate levels increases (19). The addition of glycerol results in a higher proportion of water and, consequently, water containing condensate in the smoke. The resulting "dilution" of the tobacco in the cigarette with glycerol is reflected in lower values for all tobaccospecific components in mainstream smoke. This effect is described in the literature $(48,49)$ and was confirmed in our study.

CARMINES and GAWORSKI (19) examined 34 mainstream smoke components together with condensate, nicotine and carbon monoxide, following the addition of 5, 10 and 15\% glycerol to the tobacco of test cigarettes (the highest level in our study was 5\%). They observed no significant effect on benzo[a]pyrene yields, while the addition of 10 and $15 \%$ glycerol to the tobacco resulted in slight decreases of the formaldehyde and acetaldehyde levels. According to CARMINES and GAWORSKI (19) the addition of about 5\% glycerol to cigarette tobacco had no effect on 1,3-butadiene levels in cigarette mainstream smoke. However, unrealistically high levels of glycerol in tobacco $(10 \%$ and $15 \%$ ) were noted to cause a significant increase of acrolein by $9 \%$. Acrolein as a constituent of cigarette smoke was not included in our study but should be taken into consideration in future chemical analyses of smoke.

In our study, the addition of cocoa powder produced no substantial effects on most of the investigated analytes. It is noticeable that cocoa powder caused the most pronounced decrease in the tobacco-specific nitrosamines. Cocoa powder may possibly have an influence on the intensity of the burning process, resulting in reduced transfer of TSNAs from tobacco into cigarette mainstream smoke. According to FISCHER et al. (50) TSNAs in mainstream smoke are transferred directly from tobacco into smoke. However, in 2008, MOLDOVEANU and BORGERDING (51) reported the generation of small amounts of TSNAs from nicotine and nornicotine during smoking. Reduction of the generation of such small amounts of TSNAs by smoking a cigarette cannot explain the decrease of TSNAs observed in our study when cigarettes contained cocoa powder as tobacco additive. The authors are aware of only one published chemical smoke analysis investigating cocoa or cocoa products as a single-substance tobacco additive. In the 1970s, the American National Cancer Institute carried out a multiple test series to investigate the effect of certain selected tobacco additives on the composition and biological effects of tobacco smoke. The addition of $1 \%$ cocoa powder resulted in an increase of phenol, isoprene, indole, cresols, catechol and various fatty acids in mainstream smoke (52). On the other hand, no increase in isoprene was observed in our study.

The addition of sugar compounds to tobacco is assumed to increase the formation of various aldehydes (28).

In our study, only slight increases were observed in some of the analyzed mainstream smoke constituents of test cigarettes with added sucrose. For example, a slight increase was observed for 1,3-butadiene.

On the other hand, sucrose in tobacco has a noticeable influence on the level of formaldehyde in mainstream smoke. In our study a considerable increase was observed for the highest level of added sucrose $(5 \%)$ in the mainstream smoke of the $10 \mathrm{mg}$ condensate cigarette. In mainstream smoke of the $6 \mathrm{mg}$ condensate cigarette the effect of the sucrose in tobacco on formaldehyde yields was also seen in the test cigarettes with the highest amount of added sucrose though less pronounced than in the $10 \mathrm{mg}$ condensate cigarette. Studies published by the tobacco industry confirm the effect of tobacco sugars on formaldehyde yields in cigarette mainstream smoke (47). The influence of various types of sugar as tobacco additives was investigated in terms of composition of mainstream smoke, particularly with regard to the yields of various aldehydes. The $10.5 \%$ addition of white sugar (consisting of more than $98 \%$ sucrose) resulted in a $40 \%$ increase of formaldehyde from $30 \mu \mathrm{g} / \mathrm{cig}$ to $42 \mu \mathrm{g} / \mathrm{cig}$. All these values are in line with the formaldehyde values determined in the mainstream smoke of cigarette brands from the open market, when these cigarettes were machine-smoked according to the ISO smoking regimes $(53,54)$.

Acetaldehyde has been discussed with regard to its possible addiction enhancing effect in tobacco smoke (28, 55). Levels between $50 \mu \mathrm{g}$ and $850 \mu \mathrm{g}$ acetaldehyde were detected in the mainstream smoke of various cigarettes smoked according to standardized ISO methods $(53,54)$. In our study, the amounts of acetaldehyde in the mainstream smoke of the $10 \mathrm{mg}$ condensate cigarettes were about $400 \mu \mathrm{g}$, for the $6 \mathrm{mg}$ condensate cigarettes about $290 \mu \mathrm{g}$. No increase in acetaldehyde yields was observed with the addition of sucrose to tobacco. It was not possible to confirm the assumption that the addition of sucrose results in higher levels of acetaldehyde. However, publications indicate that there is a correlation between the 
acetaldehyde level in mainstream smoke and the condensate of a cigarette (56).

With consumer protection in mind, the question arises whether the additives, glycerol, cocoa powder and sucrose, in the presence of tobacco produce an identifiable increase in substances with toxic relevance when a cigarette is being smoked. In this study certain trends were observed, of which some are in agreement with published data, e.g. the decrease in tobacco-specific nitrosamines when glycerol is added. The most significant result is the elevated formation of smoke formaldehyde when a high quantity of sucrose is added to cigarette tobacco. Generally, the data presented in our paper do not indicate any substantial effects of the three tobacco additives on most of the analytes examined.

\section{CONCLUSIONS}

In order to create a broad data base for the scientific assessment of the effects of tobacco additives on the toxicity of cigarette mainstream smoke, it is recommended to enlarge the range of additives in a study set up like our investigation. Furthermore, it would be appropriate to include other smoke components in the analytical program for the assessment of additive effects. The so-called "Hoffmann analytes", as mandated for cigarettes by the Canadian authorities (57), could be used as the starting point. These analytes came to be known when, in the late 1990s, a list was drawn up of the supposedly most important toxic substances in tobacco smoke assumed to have particular relevance for smoking-related diseases. This list included about 44 substances referred to as "Hoffmann analytes", named after the scientist DIETRICH HOFFMANN and his ground-breaking work in recent decades in the field of tobacco, tobacco smoke and its toxicity $(58,59,60)$.

Generally, there is a need for the systematic evaluation of the additives used in tobacco products. The evaluation should be carried out under standardized conditions using a defined assessment scheme. However, to date there are no binding directives, evaluated or official methods/test systems available to produce a data set, which would permit the overall systematic appraisal of additives for tobacco products.

There is a draft document on the assessment of tobacco additives issued by Deutsches Krebsforschungszentrum Heidelberg (DKFZ, German Cancer Research Center, Heidelberg). It points out that the assessment of tobacco additives should correspond to the assessment of pharmacological products and essentially be based on pyrolysis data of the neat additives (61).

Another advanced option for a toxicological assessment strategy in four stages could be as follows (Figure 13):

Stage 1: A basic prerequisite for the use of an additive in tobacco products is that it is not harmful/toxic in unburned form. Stage 1 should, therefore, consist of the characterization and toxicological evaluation of the additive in unburned form based on already published data provided by national or international expert bodies. If data are not available, the individual additives should be tested using recognized toxicological test methods in consideration of their mode of action (possible methods include, e.g., the OECD Guidelines (Organization for Economic Cooperation and Development) (62).

Stage 2: For additives that are burned in a tobacco product, the toxicological assessment of the unburned substance is not sufficient. Stage 2 of the assessment should include the pyrolysis of the additive as an individual substance based on a standardized method. These methods should mimic the conditions in a cigarette as closely as possible $(13,63)$. The compounds generated by the pyrolysis of additives provide information on which compounds may be generated from the additive during the smoking of the tobacco product. This is a prerequisite for the chemical analytical evaluation of toxic substances in the smoke of additive containing tobacco products, such as cigarettes.

If components are present in a pyrolysate for which no data on their toxic effects are available, the components should be tested using recognized toxicological test methods, once again considering their mode of action. The OECD Guidelines should be used, as already indicated for stage 1.

Using glycerol, cocoa powder and sucrose as examples, the literature cited in the introduction shows that the chosen experimental conditions of the pyrolysis studies have a major effect on which pyrolysis products are generated and in which quantities. As mentioned above, if pyrolysis studies are to be used as part of an assessment strategy for additives, it would be necessary to develop a standardized, validated method.

However, this method can only illustrate an additive's potential to generate substances or substance classes under the influence of heat. Pyrolysis experiments cannot clarify how an additive behaves in a burning cigarette. Smoking a cigarette is a complex process that consists of a number of different phases, such as combustion, pyrolysis, pyrosynthesis, distillation and sublimation. The thermal decomposition by pyrolysis is controlled by the levels, and variations, of the experimental temperature and the oxygen levels present in the pyrolysis apparatus. It is not possible to mimic the conditions and processes in a cigarette during smoking completely by means of pyrolysis experiments with individual substances.

When tobacco is smoked, it generates a large number of toxic and carcinogenic substances. Up to now, more than 5000 different substances were identified in cigarette smoke (10) and more than 70 substances in tobacco smoke categorized as carcinogenic or very probably carcinogenic by leading national and international organizations and expert bodies (11). Toxic substances are certainly generated when additives or any organic materials are burned and pyrolyzed. During the smoking process, the products generated from additives also react with certain other components of tobacco smoke. In order to take account of the contribution of tobacco additives to the toxic and addictive effects of cigarette mainstream smoke with due consideration of possible synergetic effects and to answer the question whether the additives influence the quantitative share of toxic substances in whole smoke, the pyrolysis of additives itself is not sufficient as an assessment criterion.

Stage 3: In a third stage, all tobacco additives with a share 


\section{Model for a toxicological assessment strategy of tobacco additives}

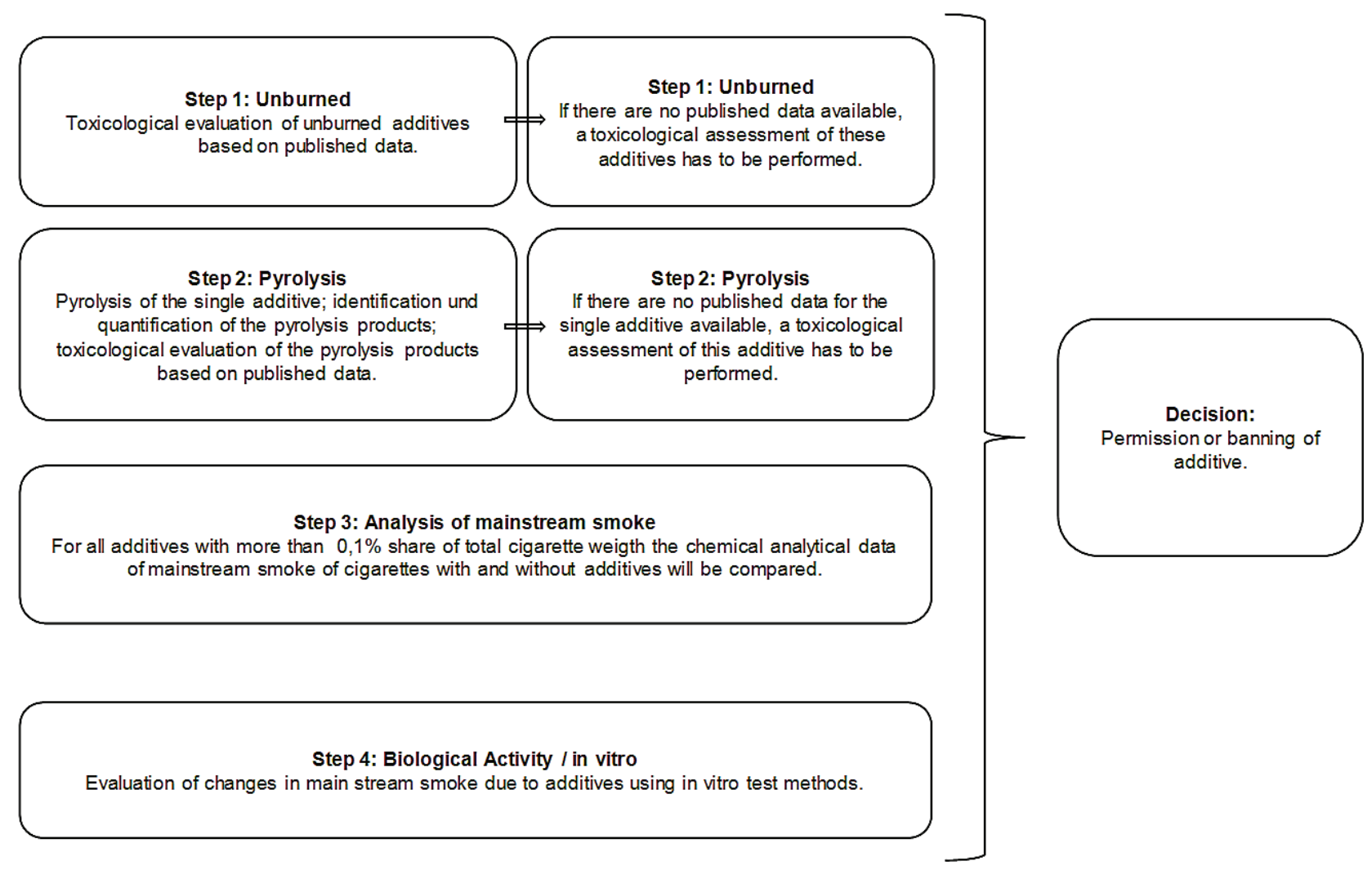

Figure 13. Model for a toxicological assessment strategy in four stages.

of greater than $0.1 \%$ of total cigarette weight should be evaluated with respect to their effects on selected compounds in mainstream smoke using cigarettes that contain these additives. Standardized methods with a standardized test cigarette (design, tobacco blend, individual substances and/or their mixtures) should be used. Many methods and techniques needed for this purpose are already established. Mainstream smoke of tobacco products should be compared without and with additives, as was done in our study. Two inclusion levels are appropriate. The "lower" level should be set in a way that $90 \%$ of the cigarettes on the market contain the additive in amounts equal to, or lower than, this level. In addition, the additive should be examined at an inclusion level ten times the "lower" level if it is technically feasible. The actual inclusion levels of the various additives used in cigarette manufacturing can be learned by evaluating the additive lists of all brand cigarettes sent each year by the tobacco industry (in Germany) to the Federal Office of Consumer Protection and Food Safety (Bundesamt für Verbraucherschutz und Lebensmittelsicherheit, BVL) - or to the respective authorities in the other EU member states. In particular, additives used in larger quantities ( $\geq 1 \%$ in tobacco) should not be tested in additive mixtures but as individual substances.

Stage 4: However, an analysis of smoke that looks at a limited number of smoke constituents only depicts a certain part of tobacco smoke, which is known to contain at least 5,000 different substances. Although smoke analysis is an essential tool in the toxicological assessment of additives, the actual influence of an additive on the overall toxicity of tobacco smoke can only be clarified by in vitro or in vivo tests using biological systems. Studies that measure changes in the biological response to smoke, therefore, constitute an additional tool for the assessment and regulation of additives.

However, up to now there are no internationally recognized directives, evaluated methods or test systems for the toxicological assessment of additives or tobacco products in general. An initial step towards assessment and in the on-going development of the toxicological testing of tobacco additives was taken by the DIN Report 133 of 2004 titled "Toxikologische Bewertung von Zusatzstoffen für Tabakprodukte - Ein Leitfaden" (Toxicological Assessment of Additives for Tobacco Products - A Guideline). This document is regularly reviewed and currently being revised (64).

If the potential toxic effects of an additive in cigarette mainstream smoke are evaluated in biological test systems it is important that fresh, un-aged smoke is used for the evaluation. Ageing of cigarette smoke results in the decrease of its toxic properties and artifact formation (65). In vitro and in vivo data obtained with aged cigarette smoke or cigarette smoke condensate do not reflect reality.

Article 11 of the EU Directive 2001/37/EU (8) states that 
the Commission shall pay special heed to the on-going development of methods for more realistically assessing and regulating toxic exposure and harm from tobacco products. In the U.S., the Food and Drug Administration (FDA) was given regulatory authority over tobacco products in 2009. The FDA has been given 42 months to draw up test procedures for additives in tobacco products (66). Which test procedures should be used in the EU for the evaluation of tobacco additives remains an open question.

Finally, a basic review on the effects of tobacco additives on mainstream cigarette smoke should take a critical approach. As a matter of fact, the consumer smokes not only additives but a product with approx. $90 \%$ tobacco content. To ensure practical consumer protection for the smokers of cigarettes and other tobacco products, an important aspect is looking at which harmful substances are inhaled, and possibly taken up, by the smoker. The measurement and notification of substances with toxicological relevance in mainstream smoke constitutes another possibility for assessing and regulating tobacco products. Furthermore, the introduction of maximum levels for certain smoke components could reduce consumer exposure to harmful substances.

\section{ACKNOWLEDGEMENTS}

The authors wish to express their gratitude to Dr. W. Hörtig (head of the CVUA Sigmaringen) for the support of this research. We would like to thank all technicians and scientists who participated in the study, especially Sabine Nebe and Robert Burk for their excellent work in the laboratory and the department for measurement at the CVUA Sigmaringen.

Furthermore we would like to thank the German Federal Ministry for Food, Agriculture and Consumer Protection (BMELV) and the Federal Office of Consumer Protection and Food Safety (BVL) for supporting the project. The authors are grateful to the group of persons who supported the project by fruitful discussions or by providing valuable editorial input.

\section{REFERENCES}

1. Bundesrepublik Deutschland: Gesetz über den Verkehr mit Lebensmitteln, Tabakerzeugnissen, kosmetischen Mitteln und sonstigen Bedarfsgegenständen [Federal Republic of Germany: Law on the commercial use of foods, tobacco products, cosmetics and consumer goods]; 15. August 1974, Bundesgesetzblatt, BGBl I.

2. European Commission: Regulation (EC) No $178 / 2002$ of the European Parliament and of the Council of 28 January 2002 laying down the general principles and requirements of food law, establishing the European Food Safety Authority and laying down procedures in matters of food safety.

3. Bundesrepublik Deutschland: Lebensmittel-, Bedarfsgegenstände- und Futtermittelgesetzbuch (LFGB) in der Fassung der Bekanntmachung vom
24. Juli 2009 (BGB1. I S. 2205), das durch die Verordnung vom 3. August 2009 (BGBl. I S. 2630) geändert worden ist [Federal Republic of Germany: Code on foods, consumer products and feed in the version of July 24, 2009 (BGBI. I p. 2205) last amended by the law of August 3, 2009 (BGBl. I p. 2630)].

4. Bundesrepublik Deutschland: Vorläufiges Tabakgesetz in der Fassung der Bekanntmachung vom 9. September 1997 (BGB1. I S. 2296), das zuletzt durch das Gesetz vom 6. Juli 2010 (BGBl. I S. 848) geändert worden ist [Federal Republic of Germany: Provisional tobacco law in the version of September 9, 1997 (Bundesgesetzblatt, BGBl. I p. 2296), last amended by the law of July 6, 2010 (Bundesgesetzblatt, BGB1. I p. 848)].

5. Bundesrepublik Deutschland: Tabakverordnung vom 20. Dezember 1977 (BGBl. I S. 2831), die zuletzt durch die Verordnung vom 6. Juli 2010 (BGB1. I S. 851) geändert worden ist [Federal Republic of Germany: Tobacco Ordinance of December 20, 1977 (Bundesgesetzblatt, BGB1. I p. 2831), last amended by the ordinance of July 6, 2010 (Bundesgesetzblatt, BGBl. I p. 851)].

6. Bundesrepublik Deutschland: Aromenverordnung in der Fassung der Bekanntmachung vom 2. Mai 2006 (BGB1. I S. 1127), die zuletzt durch Artikel 1 der Verordnung vom 30. September 2008 (BGBl. I S. 1911) geändert worden ist [Federal Republic of Germany: Flavoring Ordinance in the version of May 2, 2006 (Bundesgesetzblatt, BGB1. I p. 1127), last amended by article 1 of the Ordinance of September 30, 2008 (Bundesgesetzblatt, BGB1. I p. 1911)].

7. Bundesrepublik Deutschland: Tabakprodukt-Verordnung vom 20. November 2002 (BGB1. I S. 4434), die zuletzt durch Artikel 360 der Verordnung vom 31. Oktober 2006 (BGBl. I S. 2407) geändert worden ist [Federal Republic of Germany: Tobacco Products Ordinance of November 20, 2002 (Bundesgesetzblatt, BGBl. I p. 4434), last amended by article 360 of the Ordinance of October 31, 2006 (Bundesgesetzblatt, BGBl. I p. 2407)].

8. European Commission: Directive 2001/37/EC of the European Parliament and of the Council of June 5, 2001 on the approximation of the laws, regulations and administrative provisions of the Member States concerning the manufacture, presentation and sale of tobacco products. Off. J. Eur. Commun. L194 (2001) 26-34.

9. Doull, J., J.P. Frawley, W.J. George, T.A. Loomis, R.A. Squire, and S.L. Taylor: List of ingredients added to tobacco in the manufacture of cigarette by six major American cigarette companies; Covington and Burling, Washington, D.C., April 12, 1994 (INT517941576 -1600).

10. Rodgman, A. and T.A. Perfetti: The chemical components of tobacco and tobacco smoke; Taylor and Francis Group (2009).

11. International Agency for Research on Cancer (IARC): Mainstream cigarette smoke in: Tobacco Smoke and Involuntary smoking; Vol. 83 Monographs on the evaluation of carcinogenic risks 
to humans, Lyon, 2004, pp. 68-88.

12. International Organization for Standardization(ISO): ISO 3308 Routine analytical cigarette-smoking machine - Definitions and standard conditions. Geneva, ISO (2000).

13. Baker, R.R. and L.J. Bishop: The pyrolysis of tobacco ingredients; J. Anal. Appl. Pyrolysis 1 (2004) 223-311.

14. Laurene, A.H., R.H. Cundiff, and G.H. Greene: Determination of glycerol and propylene glycol in cigarette smoke; Tob.Sci. 9 (1965) 1-4.

15. Rodgman, A.: Some Studies of the Effects of Additives on Cigarette Mainstream Smoke Properties. II. Casing Materials and Humectants; Beitr. Tabakforsch. Int. 20 (2002) 279-299.

16. Liu, C.: Glycerol Transfer in Cigarette Mainstream Smoke; Beitr. Tabakforsch. Int. 21 (2004) 111-116.

17. Kröller, E.: Ergebnisse von Schwelversuchen an Zusatzstoffen $\mathrm{zu}$ Tabakwaren. 2. Mitteilung (Polyglykole, Glycerin) [Kröller, E.: Results of smoldering experiments with additives for tobacco products. 2nd Communication (polyglycols, glycerol)]; Deutsche Lebensmittel-Rundschau 61 (1965) 16.

18. Stein, Y.S., M.J.Jr. Antal, and M.Jr. Jones: A study of the gas-phase pyrolysis of glycerol; J. Anal. Appl. Pyrolysis 4 (1983) 283-296.

19. Carmines, E.L. and C.L. Gaworski: Toxicological evaluation of glycerin as a cigarette ingredient; Food Chem. Toxicol. 43 (2005) 1521-1539.

20. Yip, S.H., L.T. Taylor, M. Ashraf-Khorassani, J. Yu, M.F. Borgerding, W.M. Coleman III, and J.A. Bodnar: HPLC-MS Determination of Acrolein and Acetone Generated from ${ }^{13} \mathrm{C}_{3}$-Labeled Glycerol Added to Cigarette Tobacco Using Two MachineSmoking Regimes; Beitr. Tabakforsch. Int. 24 (2010) 48-57.

21. Baker, R.R. and L.J. Bishop: The pyrolysis of nonvolatile tobacco ingredients using a system that simulates cigarette combustion conditions; J. Anal. Appl. Pyrolysis 74 (2005) 145-170.

22. Gager, F.L. Jr., J.W. Nedlock and W.J. Martin: Tobacco additives and cigarette smoke. I. Transfer of $D$-glucose, sucrose, and their degradation products to the smoke; Carbohydr. Res. 17 (1971) 327-333.

23. Gager, F.L. Jr., J.W. Nedlock and W.J. Martin: Tobacco additives and cigarette smoke. II. Organic, gas-phase products from $D$-glucose and sucrose; Carbohydr. Res. 17 (1971) 335-339.

24. Sanders, E.B., A.I. Goldsmith, and J.I. Seeman: A model that distinguishes the pyrolysis of $D$-glucose, $D$-fructose, and sucrose from that of cellulose. Application to the understanding of cigarette smoke formation; J. Anal. Appl. Pyrolysis 66 (2003) 29-50.

25. Paschke, T., G. Scherer, and W.-D. Heller: Effects of Ingredients on Cigarette Smoke Composition and Biological Activity: A Literature Overview; Beitr. Tabakforsch. Int. 20 (2002) 107-247.

26. Hoffmann, D. and I. Hoffmann: Tobacco Smoke Components; Beitr. Tabakforsch. Int. 18 (1998) 49-52.

27. Fowles, J. and E. Dybing: Application of toxicological risk assessment principles to the chemical constituents of cigarette smoke; Tob. Control 12 (2003) 424-430.

28. Talhout, R., A. Opperhuizen, and J.G. van Amsterdam: Sugars as tobacco ingredient: Effects on mainstream smoke composition; Food Chem. Toxicol. 44 (2006) 1789-1798.

29. Deutsches Krebsforschungszentrum(Hrsg.): Erhöhte Gesundheitsgefährdung durch Zusatzstoffe in Tabakerzeugnissen - Konsequenzen für die Produktregulation [German Cancer Research Center, Ed.: Increased health risks due to ingredients in tobacco products - Consequences for product regulation]; Heidelberg 2005, Available from (Accessed August 2010): http://www.dkfz.de/de/rauchertelefon/ download/Factsheet_Zusatzstoffe.pdf .

30. Rambali, B., I. Van Ändel, E. Schenk, G. Wolterink, G. van de Werken, H. Stevenson, and W. Vleeming: The contribution of cocoa powder additive to cigarette smoking addiction; RIVM report 650270002/2002 (2002), Bilthoven: Rijksinstituut voor Volksgezondheid en Milieu RIVM (National Institute for Public Health and Environment). Available from (Accessed August 2010): http://rivm.open repository.com/rivm/bitstream/10029/9279/1/ 650270002.pdf

31. Action on smoking and health (ASH): Bates, C., M. Jarvis, and G. Connolly: Tobacco additives. Cigarette engineering and nicotine addiction; (1999) Available from (Accessed August 2010): http:// www.ash.org.uk/files/documents/ASH_623.pdf.

32. Deutsches Krebsforschungszentrum (Hrsg.): Die Tabakindustriedokumente I: Chemische Veränderungen an Zigaretten und Tabakabhängigkeit [German Cancer Research Center, Ed.: Tobacco industry documents I: Chemical changes in cigarettes and tobacco addictiveness] Heidelberg, 2005; Available from (Accessed August 2010): http://www.dkfz.de/ de/tabakkontrolle/download/Publikationen/RoteRei he/Tabakindustriedokumente I.pdf.

33. Phillpotts, D.F., D. Spincer, and D.T. Westcott: The Effect of the Natural Sugar Content of Tobacco Upon the Acetaldehyde Concentration found in Cigarette Smoke; Beitr. Tabakforsch. Int. 8 (1975) 7-10.

34. International Organization for Standardization (ISO): ISO 3402 Tobacco and tobacco products - Atmosphere for conditioning and testing; Geneva, ISO (1999).

35. International Organization for Standardization (ISO): ISO 10315 Cigarettes - Determination of nicotine in smoke condensates - Gas-chromatographic method. Geneva, ISO (4/2000). ISO 10315 Technical Corrigendum 1: Cigarettes - Determination of nicotine in smoke condensates - Gaschromatographic method; Technical Corrigendum 1. Geneva, ISO (11/2000).

36. International Organization for Standardization (ISO): ISO 4387 Cigarettes - Determination of total and nicotine-free dry particulate matter using a routine analytical smoking machine; Geneva, ISO (2000).

37. International Organization for Standardization (ISO): 
ISO 10362-2 Cigarettes - Determination of water in smoke condensates - Part 2: Karl Fischer method; Geneva, ISO (1999).

38. International Organization for Standardization (ISO): ISO 8454 Cigarettes - Determination of carbon monoxide in the vapour phase of cigarette smoke NDIR method; Geneva, ISO (2000).

39. Health Canada: Health Canada Tobacco Reporting Regulations: Official method of Health Canada T104. Determination of selected carbonyls in mainstream tobacco smoke; 1999. Available from (Accessed August 2010): http://www.hc-sc.gc.ca/hcps/alt_formats/hecs-sesc/pdf/tobac-tabac/legislation/ reg/indust/method/_main-principal/carbonyl-eng.pdf.

40. Health Canada: Health Canada Tobacco Reporting Regulations: Official method of Health Canada T111. Determination of nitrosamines in mainstream tobacco smoke; 1999 Available from (Accessed August 200): http://hc-sc.gc.ca/hc-ps/alt_formats/ hecs-sesc/pdf/tobac-tabac/legislation/reg/indust/ method/_main-principal/nitrosamines-eng.pdf.

41. Health Canada: Health Canada Tobacco Reporting Regulations: Official method of Health Canada T103. Determination of benzo $(a)$ pyren in mainstream tobacco smoke; 1999. Available from (Accessed August 2010): http://www.hc-sc.gc.ca/hc-ps/alt formats/hecs-sesc/pdf/tobac-tabac/legislation/ $\mathrm{reg} /$ indust/method/_main-principal/benzo-eng.pdf.

42. Health Canada: Health Canada Tobacco Reporting Regulations: Official method of Health Canada T116. Determination of 1,3-butadiene, isoprene, acrylonitrile, benzene and toluene in mainstream tobacco smoke; 1999. Available from (Accessed August 2010): http://www.hc-sc.gc.ca/hc-ps/alt_ formats/hecs-sesc/pdf/tobac-tabac/legislation /reg/indust/method/_main-principal/isopren-eng.pdf.

43. Chemisches und Veterinäruntersuchungsamt Sigmaringen: Bestimmung von Feuchthaltemitteln in Tabakerzeugnissen - Gaschromatographisches Verfahren [Official Chemical and Veterinary Surveillance Institute Sigmaringen: Determination of humectants in tobacco products - Gas chromatographic method]; (2003) CVUA Sigmaringen; Prüfverfahren 01P0800.

44. Bundesrepublik Deutschland: Bestimmung von Theobromin und Coffein in Kakao, Lebensmittel-, Bedarfsgegenstände- und Futtermittelgesetzbuch (LFGB) [Federal Republic of Germany: Determination of theobromine and caffeine in cocoa, Federal law collection concerning food, feed and consumer products (LFGB)]; L 45.00-1 (1999). Amtliche Sammlung von Untersuchungsverfahren § 64 LFGB.

45. German Institute for Standardization (DIN): DIN 10371 Analysis of tobacco and tobacco products Determination of glucose, fructose and sucrose contents - Method using high performance liquid chromatography; Berlin, Beuth (2001).

46. Baker, R.R.: Smoke chemistry; in: Tobacco. Production, Chemistry and Technology, edited by D.L. Davis and M.T. Nielsen, Blackwell Science Ltd, 1999, Chapter 12, pp. 398-439.
47. Baker, R.R: The generation of formaldehyde in cigarettes. Overview and recent experiments; Food Chem. Toxicol. 44 (2006) 1799-1822.

48. Rustemeier, K., R. Stabbert, H.J. Haussmann, E. Roemer, and E.L. Carmines: Evaluation of the potential effects of ingredients added to cigarettes. Part 2: Chemical composition of mainstream smoke; Food Chem.Toxicol. 40 (2002) 93-104.

49. Baker, R.R., J. R. Pereira da Silva, and G. Smith: The effect of tobacco ingredients on smoke chemistry. Part II: Casing ingredients; Food Chem. Toxicol. Suppl 42 (2004) 39-52.

50. Fischer S., B. Spiegelhalder, J. Eisenbarth, and R. Preussmann: Investigations on the origin of tobacco specific nitrosamines in mainstream smoke of cigarettes; Carcinogenesis 11 (1990) 723-730.

51. Moldoveanu S.C. and M.F. Borgerding: Formation of Tobacco Specific Nitrosamines in Mainstream Cigarette Smoke; Part 1, FTC Smoking; Beitr. Tabakforsch. Int. 23 (2008) 19-31.

52. NCI, National Cancer Institute, Smoking and Health Program: Toward less hazardous cigarettes: Report No. 3. The third set of experimental cigarettes; DHEW Publication (1977).

53. Roemer, E., R. Stabbert, K. Rustemeier, D.J. Veltel, T.J. Meisgen, W. Reininghaus, R.A. Carchman, C.L. Gaworski, and K.F. Podraza: Chemical composition, cytotoxicity and mutagenicity of smoke from US commercial and reference cigarettes smoked under two sets of machine smoking conditions; Toxicology 195 (2004) 31-52.

54. Counts, M.E., F.S. Hsu, S.W. Laffoon, R.W. Dwyer and R.H. Cox: Mainstream smoke constituent yields and predicting relationships from a worldwide market sample of cigarette brands: ISO smoking conditions; Regul. Toxicol. Pharmacol. 39 (2004) 111-134.

55. Van Andel, I., E. Schenk, B. Rambali, G. Wolterink, G. van de Werken, H. Stevenson, L.A.G.J.M. van Aerts, and W. Vleeming: The health- and addictive effects due to exposure to aldehydes of cigarette smoke. Part 1: Acetaldehyde, Formaldehyde, Acrolein and Propionaldehyde; RIVM report 650270003/20021-98 Bilthoven (2002); Available from (Accessed August 2010): http://rivm. openrepository.com/rivm/bitstream/10029/9280/1/ 650270003.pdf.

56. Seeman, J.I., S.W. Laffoon, and A.J. Kassman: Evaluation of relationships between mainstream smoke acetaldehyde and 'tar' and carbon monoxide yields in tobacco smoke and reducing sugars in tobacco blends of U.S. commercial cigarettes; Inhal.Toxicol. 15 (2003) 373-395.

57. Health Canada methods (Accessed November 2010); http://www.hc-sc.gc.ca/hc-ps/tobac-tabac/legislation /reg/indust/method/index-eng.php\#main

58. Borgerding, M.F., J.A. Bodnar, and D.E. Wingate: The 1999 Massachusetts benchmark study: final report. (2000) pp. 1-141; Available from (Accessed August 2010): http://legacy.library.ucsf.edu /tid/yek21 c00/pdf;jsessionid=47AC7021F2B1980 A92E552D968974EC4. 
59. Hoffmann, D., I. Hoffmann, and K. El-Bayoumy: The less harmful cigarette: a controversial issue. A tribute to Ernst L. Wynder; Chem. Res. Toxicol. 14 (2001) 767-790.

60. Rodgman, A. and C.R. Green: Toxic Chemicals in Cigarette Mainstream Smoke - Hazard and Hoopla; Beitr. Tabakforsch. Int. 20 (2003) 481-545.

61. Deutsches Krebsforschungszentrum(Hrsg.): Zusatzstoffe in Tabakprodukten 1, Regulierungsbedarf zum Schutz der Gesundheit: Empfehlungen für eine Prüfstrategie für Tabakzusatzstoffe [German Cancer Research Center, Ed.: Additives in tobacco products 1 , Need of regulations for health protection: Recommendations for a testing strategy for tobacco additives]; Heidelberg, 2010:. Available from (Accessed August 2010): http://www.dkfz.de/de/tabakkontrolle /download/Publikationen/Fakten/Factsheet_Pruefst rategie_fuer_Tabakzusatzstoffe.pdf.

62. Organisation for Economic Co-Operation and Developement OECD: OECD Guidelines for Testing of Chemicals - Full List of Test Guidelines, August 2010. Available from (Accessed October 2010): http://www.oecd.org/dataoecd/8/11/42451771.pdf.

63. Stotesbury, S., H. Digard, L. Willoughby, and A. Couch: The Pyrolysis of Tobacco Additives as a Means of Predicting their Behaviour in a Burning Cigarette; Beitr. Tabakforsch. Int. 18 (1999) 147-163.

64. Deutsches Institut für Normung (DIN): DIN Fachbericht 133, Toxikologische Bewertung von Zusatzstoffen für Tabakprodukte - Ein Leitfaden [German
Institute for Standardization (DIN): DIN Report 133: Toxicological evaluation of additives for tobacco products - a guideline]; Beuth Verlag, Berlin, Wien, Zürich, 2004: Available from (Accessed August 2010): http://www.beuth.de/langanzeige/DIN-Fachbericht $+133 / 72463870 . h t m l$.

65. Borgerding, M.F. and H. Klus: Analysis of complex mixtures - cigarette smoke; Exp Toxicol Pathol. 57 Suppl 1(2005)43-73.

66. United States of America U.S.A.: Family Smoking Prevention and Tobacco Control and Federal Retirement Reform Public Law 111-31 - June 22, 2009; 123 Stat. 1776 Available from (Accessed October 2010): http://www.fda.gov/NewsEvents/PublicHealth Focus/ucm168412.htm and http://frwebgate.access .gpo.gov/cgi-bin/getdoc.cgi?dbname=111_cong_ public_laws\&docid=f:publ031.111.pdf.

Corresponding author:

Jürgen Hahn

Chemisches und Veterinäruntersuchungsamt Sigmaringen Hedingerstrasse 2/1

72488 Sigmaringen, Germany

Juergen.Hahn@cvuasig.bwl.de 